\title{
THE PRE-VENDIAN (640-610 MA) GRANITE MAGMATISM IN THE CENTRAL TAIMYR FOLD BELT: THE FINAL STAGE OF THE NEOPROTEROZOIC EVOLUTION OF THE SIBERIAN PALEOCONTINENT ACTIVE MARGIN
}

\author{
A. B. Kuzmichev1, M. K. Danukalova1, V. F. Proskurnin², \\ A. A. Bagaeva², N. I. Beresyuk², P. A. Gromov² \\ ${ }^{1}$ Geological Institute of RAS, Moscow, Russia \\ ${ }^{2}$ A.P. Karpinsky Russian Geological Research Institute (VSEGEI), Saint Petersburg, Russia
}

\begin{abstract}
Eastern part of the Central Taimyr belt is composed of Precambrian rocks penetrated by granites of the Snezhnaya complex (845-825 million years) and later overlain by mid-Neoproterozoic sin- postorogenic sedimentary deposits of the Stanovaya-Kolosova Group. Two competing concepts on the Precambrian history of the belt are discussed. The first suggests that by the middle of the Neoproterozoic amalgamation of various terrains formed the Central Taimyr microcontinent, which afterwards collided with Siberia in Vendian. 2) According to the second point of view, which is shared by the authors of this article, the belt was part of the Siberian craton from at least the Mesoproterozoic, and there is no suture that would separate it from the South Taimyr belt. To our surprise, during the field work in the South-Eastern part of the Central Taimyr belt near the proposed "Vendian sutura", assumed by the first concept, we found a granite pluton (Pregradnaya massif) intruding clastic rocks of Stanovaya-Kolosova Group. Such setting is quite uncommon for the belt and contradicted to publications, describing the mentioned clastic rocks to overlay the granites and contain their debris. Dating of the pluton confirmed the field observations - its SRIMP zircon age has proved to be $609 \pm 2 \mathrm{Ma}$, an unusually young for this region. The pluton is located in a wide deformation zone separating the Precambrian rocks (to the northwest) and the Paleozoic deposits (to the southeast). Two minor bodies of similar porphyritic granite were found in the same zone further to the southwest, and it seemed logical to assume that a chain of Vendian granites marks boundary deformation zone. However, their dating $(843 \pm 6$ и $840 \pm 5 \mathrm{Ma})$ showed that they belong to Snezhnaya complex. In this paper, we discuss two Neoproterozoic magmatic 'flare-ups' in the Central Taimyr Belt, which are dated at 845-825 and 640-610 Ma. Both 'flare-ups' are evidenced by K-rich peraluminous granite batholiths intruded the upper crust. It is most probable that each flare-up was related to a collision event completing an independent cycle in the evolution of the active margin of the Siberian paleocontinent.
\end{abstract}

Key words: Precambrian; Taimyr; Neoproterozoic; collisional granite; geochronology; Siberia Paleocontinent

For citation: Kuzmichev A.B., Danukalova M.K., Proskurnin V.F., Bagaeva A.A., Beresyuk N.I., Gromov P.A., 2019. The pre-Vendian (640$610 \mathrm{Ma}$ ) granite magmatism in the Central Taimyr fold belt: the final stage of the Neoproterozoic evolution of the Siberian paleocontinent active margin. Geodynamics \& Tectonophysics 10 (4), 841-861. doi:10.5800/GT-2019-10-4-0445.

Funding: This study was supported by the Russian Foundation for Basic Research (grants 6-05-00176 and 19-05-00926). The study of A.B. Kuzmichev and M.K. Danukalova was part of the GIN RAS Research Programme (No. 0135-2019-0051). 


\title{
ПРЕДВЕНДСКИЙ (640-610 МЛН ЛЕТ) ЭТАП ГРАНИТНОГО МАГМАТИЗМА В ЦЕНТРАЛЬНО-ТАЙМЫРСКОМ СКЛАДЧАТОМ ПОЯСЕ: ЗАВЕРШАЮЩАЯ СТАДИЯ ЭВОЛЮЦИИ АКТИВНОЙ ОКРАИНЫ НЕОПРОТЕРОЗОЙСКОГО СИБИРСКОГО ПАЛЕОКОНТИНЕНТА
}

\author{
А. Б. Кузьмичев ${ }^{1}$, М. К. Данукалова 1 , В. Ф. Проскурнин ${ }^{2}$, \\ А. А. Багаева², Н. И. Березюк², П. А. Громов² \\ ${ }^{1}$ Геологический институт РАН, Москва, Россия \\ ${ }^{2}$ Всероссийский научно-исследовательский геологический институт им. А.П. Карпинского, \\ Санкт-Петербург, Россия
}

\begin{abstract}
Аннотация: При полевом изучении докембрийских пород восточной части Центрально-Таймырского пояса обнаружен гранитный плутон, прорывающий синорогенные обломочные породы (становско-колосовская серия, предположительно 780-750 млн лет). Такие взаимоотношения нетипичны для пояса: считается, что наоборот, указанные орогенные накопления содержат обломки подобных гранитов. Датирование массива подтвердило наблюдавшиеся взаимоотношения: возраст гранитов оказался равным 610 млн лет. Столь молодые граниты ранее здесь не отмечались. Массив приурочен к широкой зоне деформаций, которая отделяет докембрийские породы (к северо-западу) от выходов деформированного палеозойского чехла (с юговостока). На простирании в этой зоне были найдены еще два гранитных массива, также сложенные калиевыми порфировидными гранитами. Их датирование (840 млн лет), однако, показало, что они относятся к распространенному в этой части Таймыра более древнему (снежнинскому) комплексу. В статье обсуждаются две вспышки гранитного магматизма, проявившегося в Центрально-Таймырском поясе в интервалах 845-825 и 640-610 млн лет, выраженные во внедрении калиевых слабопералюминиевых гранитных батолитов в верхние горизонты коры. Каждая вспышка завершает самостоятельный этап эволюции активной окраины Сибирского палеоконтинента в неопротерозое и предположительно связана с коллизионным событием. Породы второго этапа эволюции активной окраины преимущественно выходят на северо-восточной окраине Таймыра, где широко распространены надсубдукционные базальты, андезиты и риолиты позднего неопротерозоя (750-610 млн лет). Вулканиты несогласно залегают на породах мезопротерозоя, нижнего неопротерозоя, а также в синорогенных толщах середины неопротерозоя и несогласно перекрыты пестроцветными конгломератами терминального неопротерозоя.
\end{abstract}

Ключевые слова: докембрий; Таймыр; неопротерозой; коллизионные граниты; геохронология; Сибирский палеоконтинент

\section{INTRODUCTION}

The Central Taimyr fold belt is composed mainly of the irregularly metamorphosed and deformed Precambrian rocks. At the north, it is bounded by the Main Taimyr and Diabase thrust faults (Fig. 1) [Bezzubtsev et al., 1983]. They were interpreted as a suture between the Central Taimyr Belt and the Kara microcontinent collided in the late Paleozoic [e.g., Zonenshain et al., 1990; Vernikovsky et al., 1996]. The southern boundary is the Pyasina-Faddey fault separating the Central- and South-Taimyr belts (see Fig. 1). It is widely accepted that the South Taimyr Belt is composed of deformed rocks of the Siberian platform. In some publications, the Pyasina-Faddey thrust is also interpreted as a suture of Cretaceous [Zonenshain et al., 1990; Uflyand et al., 1991] or Vendian [Vernikovsky, Vernikovskaya, 2001, and their other publications] age. According to the ci- ted geologists, the Central Taimyr Belt is composed of set of the island-arc, continental and oceanic terranes amalgamated to a solid agglomerate in the Neoproterozoic and thus formed a microcontinent. The time of the accretion-collision was determined by the age of granites and volcanic rocks at 869-823 Ma [Vernikovsky, Vernikovskaya, 2001; Proskurnin et al., 2014]. In the mid-Neoproterozoic orogeny was completed by accumulation of clastic rocks (containing pebbles of above granites) overlayed with carbonate rocks and shales [Bezzubtsev et al., 1986; Makariev, 2013]. According to [Vernikovsky, 1996] and his later publications, the Central Taimyr 'accretionary belt' collided with the Siberian paleocontinent in the Vendian or prior to the Vendian, and the Pyasina-Faddey thrust is a suture.

In 2016, we participated in the VSEGEI field survey of the eastern part of the Central Taimyr Belt (see the box in Fig. 1). The studied area includes high-grade 


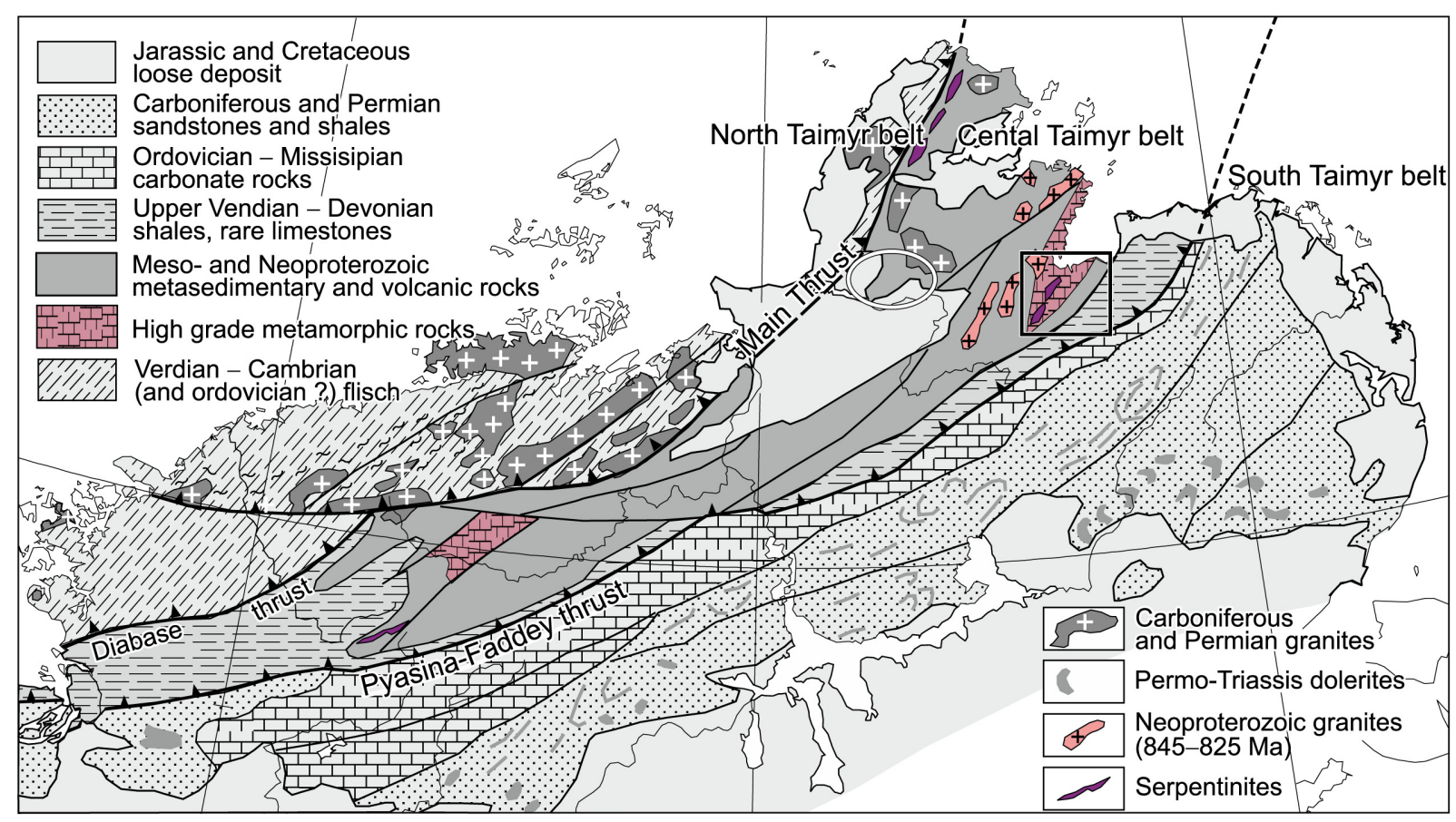

Fig. 1. Position of the Central Taimyr belt in the structural zoning of the Taimyr folded region (after [Bezzubtsev et al., 1983]). Box indicates the study area discussed in this paper; white oval - location of the Nansen (Vil'kitsky) granite suite (see Discussion).

Рис. 1. Положение Центрально-Таймырского пояса в структурной зональности Таймырской складчатой области (по [Bezzubtsev et al., 1983]). Квадратиком показано положение участка, обсуждаемого в данной статье, белым овалом показана область распространения гранитов нансеновского комплекса (см. раздел «Обсуждение»).

metamorphic rocks interpreted in different ways. They were attributed to "Faddey uplift" of the Archean or Paleoproterozoic basement of the Siberian craton [Pogrebitsky; 1971; Zabiyaka et al., 1986, Bezzubtsev et al., 1986], or the Faddey cratonic terrane being a part of the accretionary belt [Vernikovsky, Vernikovskaya, 2001; Proskurnin et al., 2014]. V.V. Bezzubtsev did not exclude that the protolith of Faddey metamorphic rocks was Riphean metasedimentary rocks that are widespread in the Central Taimyr belt [Bezzubtsev et al., 1986].

Among other interesting field observations, we found a granitic pluton intruding the above-mentioned synorogenic mid-Neoproterozoic clastic rocks. The discovery could have important implications for understanding the tectonics of Taimyr, as it was consistent with the concept of the Vendian collision of the Central Taimyr belt and the Siberian paleocontinent.

\section{OVERVIEW OF THE GEOLOGY OF THE STUDY AREA}

Our field observations had shown that in the eastern part of the Central Taimyr Belt no terrain can be delimited, which could be interpreted as an exotic "cratonic terrane" or an ancient basement uplift. Three zones of metamorphism can be roughly outlined (Fig. 2): (i) the zone of migmatized rocks (anatexis zone) that may correspond to high amphibolite facies and, probably, granulite facies (index minerals are lacking); (ii) the intermediate zone of amphibolite and epidote-amphibolite metamorphism; and (iii) the outer zone of greenschist and epidote-amphibolite metamorphism. Rocks that have experienced mylonitization and retrograde metamorphism are abundant in this area.

In all the three zones metamorphic rocks are represented by metasedimentary crystalline schists and gneisses interlayered with quartzites and marbles and containing amphibolite bodies. On the sites of relatively weak metamorphism, metasedimentary strata were mapped as parts of the October and Zhdanov formations [Bezzubtsev et al., 1983; Zabiyaka et al., 1986; Makariev, 2013]. The age range of detrital zircons from quartzites sampled from the anatexis zone is similar to that of the October and Zhdanov Formations, and thus supports the above-mentioned assumption of V.V. Bezzubtsev ([Kuzmichev, Danukalova, 2018], and unpublished data of the authors). The detrital zircons are mostly dated to the Paleoproterozoic. The youngest detrital zircons mark the lower age limit for sedimentation at 1600 Ma ([Proskurnin et al., 2009], and unpublished data of the authors). The upper age limit $(1300-1360 \mathrm{Ma})$ is determined by the age of the intruded metadolerite sills of the North Byrranga complex 


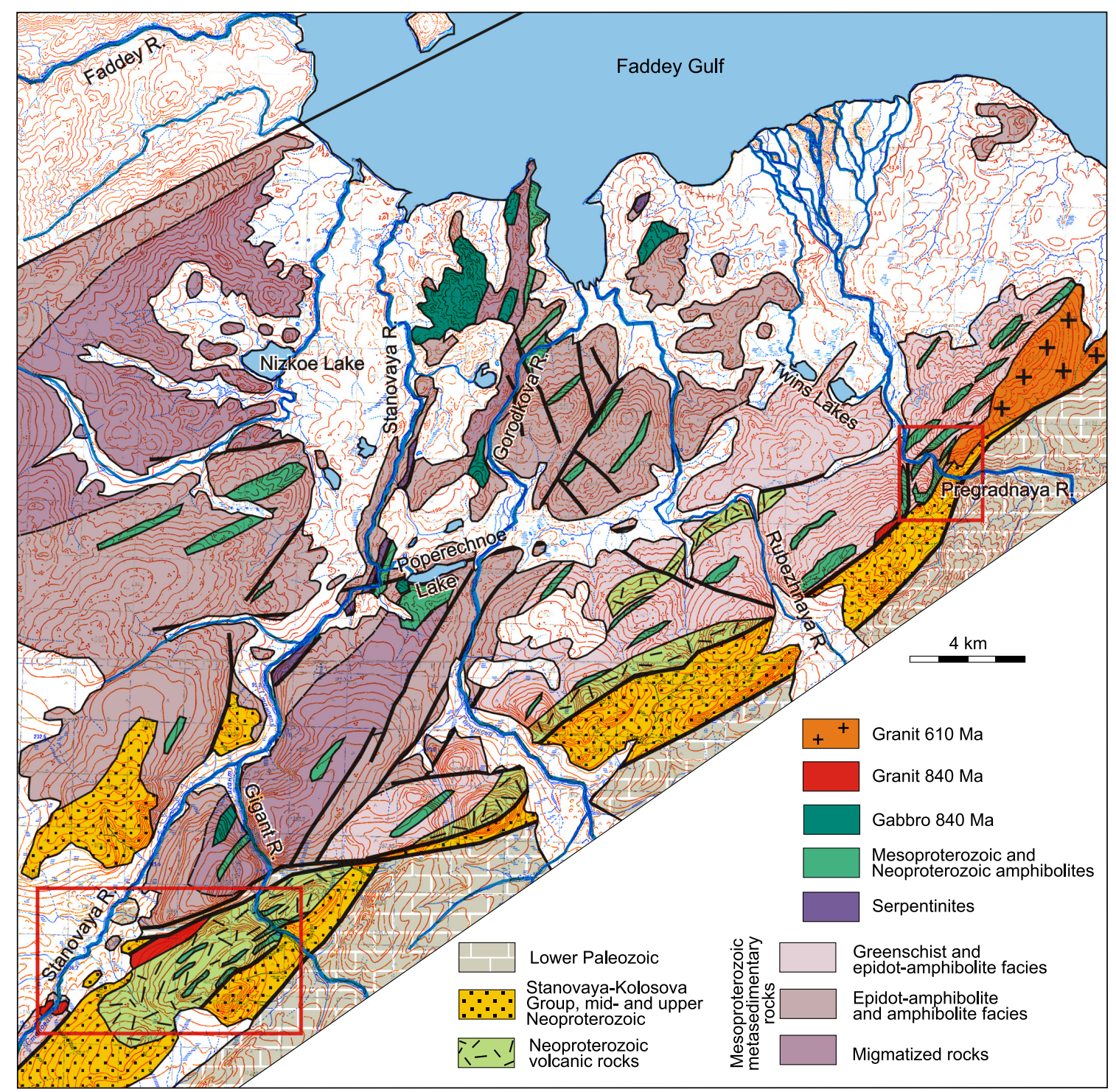

Fig. 2. Schematic geological map of the SE part of the study area. The map is based on the field observations by first two authors, the Planet satellite images (URL: https://www.planet.com) and geological maps compiled by [Stepanov et al., 1965; Makariev, 2013]. Rectangular boxes are the areas wherein the discussed granites are located (see more detailed maps in Figs. 3 and 5).

Рис. 2. Схема геологического строения юго-восточной части изученной площади (составлена первыми двумя авторами по полевым наблюдениям с использованием космических снимков Planet (URL: https://www.planet.com) и предшествующих геологических карт [Stepanov et al., 1965; Makariev, 2013]). Прямоугольниками выделены участки, включающие обсуждаемые гранитные тела и иллюстрированные более детальными схемами.

([Proskurnin et al., 2014; Priyatkina et al., 2017], and unpublished data of the authors). Similar ages were determined for detrital zircons from the October Fm. sampled further to the west (upper reaches of the Leningradskaya River) outside the Faddey metamorphic complex [Proskurnin et al., 2009] and directly westward of our study area [Priyatkina et al., 2017]. Convincing arguments for the Anabar origin of the Paleoproterozoic detrital zircons are given in the last cited paper. Our data support the conclusion of N.S. Priyatkina and her colleagues that during Meso- and Neoprote- rozoic, the southern part of the Central Taimyr belt belonged to the Siberian paleocontinent and was not separated from it by an ocean.

The early Neoproterozoic volcanic (mostly felsic) rocks occupy the next structural level. Their stratigraphic contact with the Mesoproterozoic rocks has never been observed. Volcanic rocks are partially comagmatic to the Snezhnaya granites (see below).

The Neoproterozoic granites (970-800 Ma [Kuzmichev, Danukalova, 2018]) are represented by different facies reflecting different depth levels. Migmatites and 
larger granitoid veins located in the anatexis zone. In the transition zone, there are leucogranitic dikes, generally represented by fine-crystalline rocks (not shown in Fig. 2). The zone of low-grade metamorphism contains similar dikes, small granitic bodies and relatively large medium- to coarse-crystalline granitic plutons (see Fig. 1), typically with K-feldspar phenocrysts. Granites of the latter type are shown in the maps of the Central Taimyr belt as the Snezhnaya complex [Proskurnin et al., 2009; Proskurnin et al., 2014]. Available zircon datings listed in these publications (ID TIMS and SHRIMP) are as follows: $846 \pm 11,833 \pm 14,824 \pm 3.4$, $827 \pm 22,830 \pm 5.3,833 \pm 5$, and $843 \pm 5 \mathrm{Ma}$. Thus, the age of the Snezhnaya complex is in the range of 845$825 \mathrm{Ma}$.

All the above-mentioned rocks are unconformably overlain by mid-Neoproterozoic syn- and post-orogenic deposits of the the Stanovaya-Kolosova group (more than $1000 \mathrm{~m}$ ). It comprises conglomerates and sandstones at the bottom, shallow-water carbonate rocks in the middle, and grey-coloured shales in the upper part. The group is fragmented in the study area and its complete succession is not available. The Stanovaya-Kolosova rocks are deformed and metamorphosed to lower greenschist facies (chlorite zone). To the north of the study area, these rocks are overlain by suprasubduction volcanic rocks of the late Neoproterozoic [Makariev, 2013; Markovsky et al., 2000]. All the Precambrian rocks are unconformably overlain by non-metamorphosed, strongly deformed uppermost Vendian - lower Paleozoic shales and limestones of the Siberian platform.

Deciphering of the complex fold-thrust structure of the study area is possible only for the late Vendian early Paleozoic structural level. Deformations of Stanovaya-Kolosova mid-Neoproterozoic formation are far more complex. In detailed satellite images only fold hinges composed of contrasting carbonate and shale rocks are visible. These rocks are generally form separate lense-shaped tectonic blocks, each representing only a small fragment of the Stanovaya-Kolosova group. Delineation of the Mesoproterozoic - early Neoproterozoic rock structure can hardly be practicable. In the anatexis zone, the rocks have experienced complex deformation in the plastic state. The satellite images show the general direction of foliation, which is displaced by faults of different orientations. It may be suggested that general structural motif is a set of curved reverse faults concordant with the overall structural trend. The deepseated rocks are exhumed due to displacements along these faults. The youngest normal faults and rightlateral strike-slip faults (sub-latitudinal and ENE strike) are clearly visible in the satellite images and even on topographic maps. Displacements along these faults continued in the Quaternary.

In the Neoproterozoic, the eastern part of the Central Taimyr belt has experienced orogeny twice in Neo- proterozoic: at the end of the first half and at the end of the second half. The first event was a full-scale orogeny, including granite batholith intrusion and the accumulation of the Stanovaya clastic deposits. The second event is mentioned in [Vernikovsky, 1996; Vernikovsky, Vernikovskaya, 2001; Proskurnin et al., 2014] and discussed in more detail below.

In the area shown in Fig. 2, the only relatively large granitic body is located on the right bank of the lower Pregradnaya River. According to our observations, a unique feature of these granite is its intrusion into the conglomerates of the Stanovaya Formation, i.e. these granites are younger than the above-mentioned Snezhnaya granite suites. Such setting is quite uncommon for the belt, and our discovery was unexpected and contradicting to the previous works, describing the conglomerates overlaying granites and containing granite boulders. It seemed reasonable to relate this granites to a wide tectonic zone bordering the Precambrian rocks (see Fig. 2). Further southwestward, in the same zone (at the upper reaches of the Stanovaya River), two smaller bodies of porphyritic granites similar to the above-mentioned were found, and we had no doubts that they belong to the same young suite. These three granite massifs (Pregradnaya, Stepanov and Magistral'ny) are described and discussed below.

\section{Pregradnaya MaSSIF}

Massif is located on the right bank of the Pregradnaya river in its lower reaches (see Fig. 2) and extends to the northeast in accordance with general structural trend. Its area (approx. $12 \mathrm{~km}^{2}$ ) is clearly detectable by aerial gamma-ray imaging. Several small porphyritic granite bodies were also observed on the left bank of the Pregradnaya River. They are exposed along the fault zone that separates the Precambrian metamorphosed rocks and the Stanovaya-Kolosova Group. It is probable that these are fragments of the SW continuation of the Pregradnaya massif.

The part of the massif exposed on the slopes facing the Pregradnaya River, has been studied in more detail (Fig. 3). This area is a part of a wide fault zone separating the Precambrian and Paleozoic rocks. The Precambrian rocks are mylonitized, and almost all lithological contacts are faulted. Tracing of the most recognizable rocks (e.g., dolomites of the Kolosova Fm.) suggests that, area is cut out to number of lense-shaped blocks by curved reverse faults. These faults are relatively young, considering that the Stanovaya-Kolosova rocks are displaced by them. The dip and strike data shown in the map (see Fig. 3) reflect the actual orientation of metasedimentary rock layering that coincides with foliation in this area. Observations of the metadolerites show that banding, foliation and rock contact 


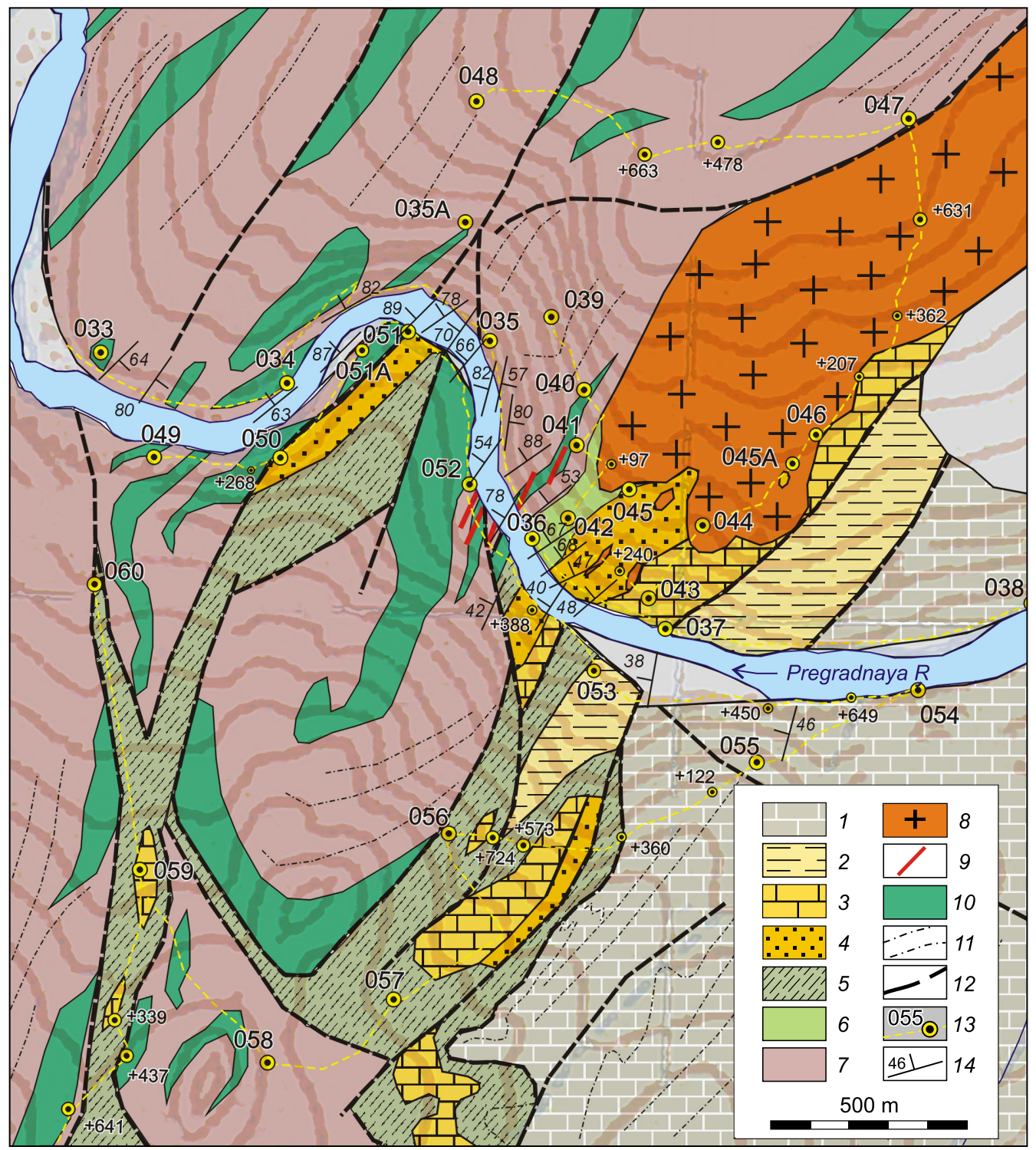

Fig. 3. Geological map of the southwestern termination of the Pregradnaya massif (mapped by first two authors). Contour interval $-20 \mathrm{~m}$.

1 - uppermost Vendian - lower Paleozoic deposits; 2-4 - Stanovaya-Kolosova group (mid-Neoproterozoic): 2 - grey shales, 3 - marbles, 4 - conglomerates, gritstones, marbles; 5 - chlorite and chlorite-sericite green schists, rare gritstones; 6 - felsic metavolcanic rocks (853 $\pm 11 \mathrm{Ma}$ ); 7 - Zhdanova Formation (Mesoproterozoic) - metasedimentary rocks including marbles and quartzites; 8 - Pregradnaya

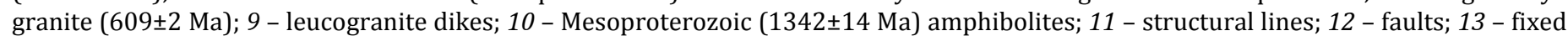
sites and tracks; 14 - dip and strike of layering, banding, foliation (all the elements have the same orientation).

Рис. 3. Геологическая карта ЮЗ замыкания Преградненского массива (составлена по наблюдениям первых двух авторов). Сечение горизонталей - 20 м.

1 - Верхневендские - нижнепалеозойские отложения; 2-4 - становско-колосовская серия (средний неопротерозой): 2 - серые сланцы, 3 - мраморы, 4 - конгломераты, гравелиты, мраморы; 5 - хлоритовые и хлорит-серицитовые зеленые сланцы, редко гравелиты; 6 - метавулканиты (853 11 млн лет); 7 - ждановская толща (мезопротерозой) - метаосадочные породы, в том числе мраморы и кварциты; 8 - граниты Преградненского массива (610 млн. лет); 9 - дайки лейкогранитов; 10 - мезопротерозойские

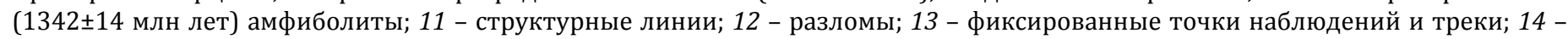
элементы залегания слоистости, полосчатости, сланцеватости (ориентировка всех перечисленных элементов совпадает).

orientations are coincident wherever such features are observed. Older rocks in Fig. 3 are replaced with younger rocks in SE direction, while most of them are inclined in the opposite direction. Presumably they are predominantly in overturned position The lower rea- ches of the Pregradnaya River is the only place in the region, wherein the rock relationships can be observed on the river bank cliffs.

The geological units oulined in the Fig. 3 are as follows: (i) Mesoproterozoic metasedimentary rocks. Pre- 
viously, these rocks were mapped as the Zhdanov Fm. due to the presence of carbonate rocks. Carbonate rocks (10-15\% of the visible thickness) represented by grey marble layers (from few centimeters to several meters thick) interbedded with various schists, micaquartzites and massive quartzites. Widespread are carbonate-silicate rocks. Due to intense deformation, an original lithological succession cannot be restored. (ii) Mesoproterozoic amphibolites of the North Byrranga complex. They form concordant bodies of a few meters up to several dozens of meters thick interpreted as sills. These are massive, slightly schistose, rarely banded black-green rocks composed of hornblende, albite and quartz with varying amounts of Fe-Ti minerals. Indistinct gabbro-dolerite structure is preserved in some sites. (iii) Neoproterozoic metavolcanic rocks with cloudy microcrystalline basis and, vague remnants of feldspar and rare quartz phenocrysts. In places they intercalate with packs of chlorite schists. (iv) Rocks of the Stanovaya-Kolosova Group. These rocks are believed to lie unconformably upon rocks listed above, but the direct contact in the study area is faulted. The lower part of the group comprises conglomerates, gritstones and sandstones interbedded with marbles. Coloured sandstones and gritstones on the left bank of the Pregradnaya River (near point 051) probably compose the lowermost horizons of the Group, which are not preserved on the right bank. These rocks associate with hematitized green schist interpreted as pre-Stanovaya weathering crust. Middle part of the Group consists of marbles. Upper part comprises grey-coloured shales and siltstones with rare sandstones. This shale unit is distinctly mappable several kilometers to the southwest, here only its fragments preserved. (v) All of the above-mentioned rocks are intruded by the Pregradnaya granites (discussed in more detail below). A set of light coloured, almost white granite veins that probably acted as feeder dikes.

Pregradnaya granites crop out at cryoplanation terraces covered with granite blocks (Fig. 4, a) and in scarps several meters high. A contour of the southwestern margin of pluton is sinuous. Here granite intrudes all pre-Stanovaya rocks, as well as Stanovaya conglomerates and marbles. Intrusive contacts can hardly be substantiated confidently considering the 'talus' or 'rubble' setting. Nonetheless, all of the abovementioned host rocks (more or less altered) are observed in xenoliths at the massif's margin. Among them Stanovaya conglomerates are the most detectable. The Pregradnaya massif is composed of medium- to coarsegrained porphyritic granite with yellowish and pink Kfeldspar phenocrysts $(1-3 \mathrm{~cm})$. Phenocrysts are roughly rounded and less commonly show euhedral habitus (Fig. 4, b, e, f). Most granites are more or less cataclased and show some schistosity with preferred phenocrysts orientation. Mafic minerals are completely or almost completely chloritized. Most intense secondary alterations are noted in the near-contact zone where rocks are pyritized and rusty.

Granites are mainly composed of three minerals: alkali feldspar, plagioclase and quartz. Alkali feldspar phenocrysts vary in number from one site to another and generally amount to $20-30 \%$ of the rock (on some sites, less than $10 \%$ or more than $50 \%$ ). The least homogeneous rock composition is observed in the nearcontact zone. In thin sections alkali feldspar is represented by perthite. Pelitization is insignificant and patchy, and it generally looks much fresher than plagioclase.

Quartz forms xenomorphic grains (up to $1 \mathrm{~cm}$ ), which in places are lense-shaped (Fig. 4, $d$ ). In thinsections quartz is granulated and shows complex undulose extinction. Cataclasis is manifested by bands of microgranular quartz.

Plagioclase is the main rock component in terms of volume. It is usually poorly distinguishable in field, although its crystals are quite distinct on some sites (Fig. $4, c)$. Plagioclase is sosuritized and looks greenish in hand specimens (Fig. 4, e, f). In thin sections it shows blurred polysynthetic twinning with dispersed secondary minerals.

Mafic minerals are represented by biotite and, rarely, amphibole. They are partially or more often completely replaced with chlorite. In thin sections biotite flakes are bent and contain chlorite lamellae, and flecked with pleochroic halos around zircon crystals and possibly some other mineral phase. Some biotite aggregations are heterogeneous in structure and colour, contain numerous inclusions of Fe-Ti minerals, and thus themselvs look like a secondary minerals. Probably, they substitute another mafic mineral, and an excessive Fe-Ti forms new mineral phase.

Among accessory minerals (separated from sample 045/1-16) dominate zircon and apatite presented in roughly equal amounts. An unusual feature is the presence of galenite, which also mentioned by [Stepanov et al., 1965]. Therefore, this is not a random mineralization, but a characteristic feature of the Pregradnaya massif.

\section{PORPHYRITIC GRANITES IN THE UPPER REACHES OF THE STANOVAYA RIVER}

The Neoproterozoic rocks predominate in the upper reaches of the Stanovaya River, and they are separated from the Mesoproterozoic rocks by Magistral'ny fault (Fig. 5). Non-metamorphosed uppermost Vendian and lower Paleozoic rocks are exposed in the fault graben and around it. A significant part of this territory is composed of the Neoproterozoic felsic metavolcanic rocks, according to [Stepanov et al., 1965]. and on some 

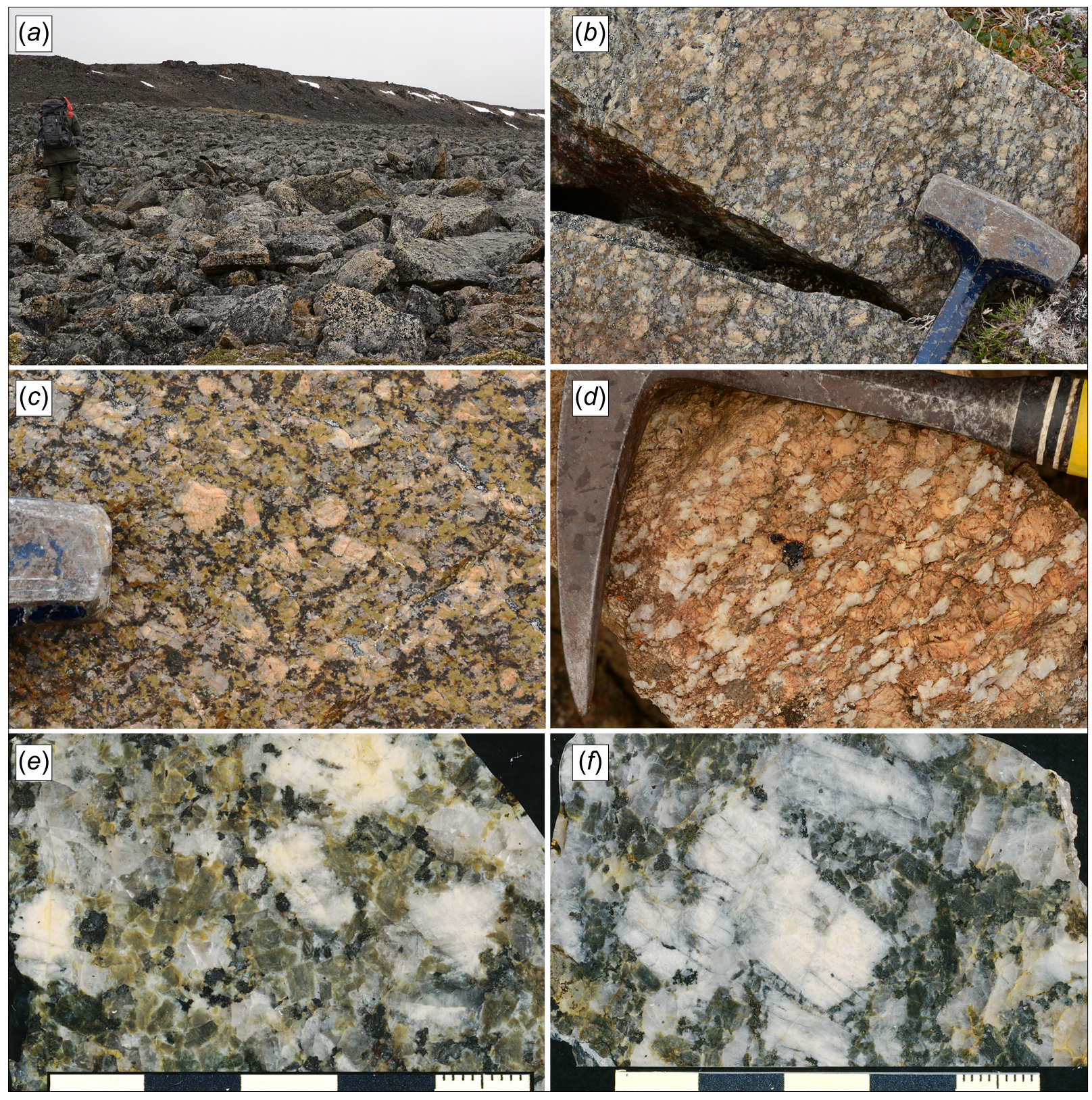

Fig. 4. Photographs of typical granites of the Pregradnaya massif.

(a) - granite talus near site 047 (see Fig. 3). The ridge in the background is composed of amphibolites and the Zhdanova Fm. metasedimentary rocks. $(b)$ - typical appearance of porphyritic granite. Phenocrysts are made of K-feldspar. $(c)$ - naturally cut rock surface showing all the major rock-forming minerals of the Pregradnaya granites: large yellowish-pink mineral - perthitic feldspar; smaller, dirtygreen - epidotized plagioclase; grey fuzzy shaped - quartz; black - chloritized biotite. $(d)$ - xenomorphic quartz (white) juts over weathered granite surface. The predominant mineral in this leucocratic variety is yellowish-pink alkali feldspar. $(e)$, $(f)$ - scanned saw-cut granite samples. Below is a ruler in centimeters. $(e)$ - sample 046/3-16. Idiomorphic tabular crystals of the saussuritized plagioclase (greenish) are visible. Light-colored mineral - xenomorphic orthoclase with inclusions of quartz, plagioclase and biotite along the periphery. Black mineral - chloritized biotite. $(f)$ - sample 044/1-16. Similar rock, but orthoclase is more idiomorphic, with quartz inclusions.

\section{Рис. 4. Фотографии типичных гранитов Преградненского массива.}

(a) - гранитный курум вблизи точки 047 (см. рис. 3). Хребтик на заднем плане сложен метаосадочными породами ждановской толщи и амфиболитами. $(b)$ - типичный порфировидный облик пород. Вкрапленники сложены калиевым полевым шпатом. (c) - естественный скол глыбы, на котором видны все главные породообразующие минералы гранитов: крупный желторозовый минерал - ортоклаз-пертит, более мелкий грязно-зеленый - эпидотизированный плагиоклаз, серый нечетко оформленный - кварц, черный - хлоритизированный биотит. Слева видна часть кувалды (той же, что и на предыдущей фотографии). $(d)$ - выветрелая поверхность гранита с отпрепарироваными ксеноморфными выделениями кварца (белое). Преобладающий минерал в этой лейкократовой разновидности - желтовато-розовый ортоклаз-пертит. $(e),(f)$ - сканированные спилы образцов гранита. Внизу - линейка в сантиметрах. (e) - образец 046/3-16. Видны идиоморфные таблички соссюритизированного плагиоклаза (зеленоватые). Светлое - ксеноморфный ортоклаз с включениями кварца, плагиоклаза и биотита по периферии. Черное агрегат хлоритизированного биотита. $(f)$ - образец 044/1-16. Сходная порода, но ортоклаз имеет четкие очертания. В нем видны включения кварца. 


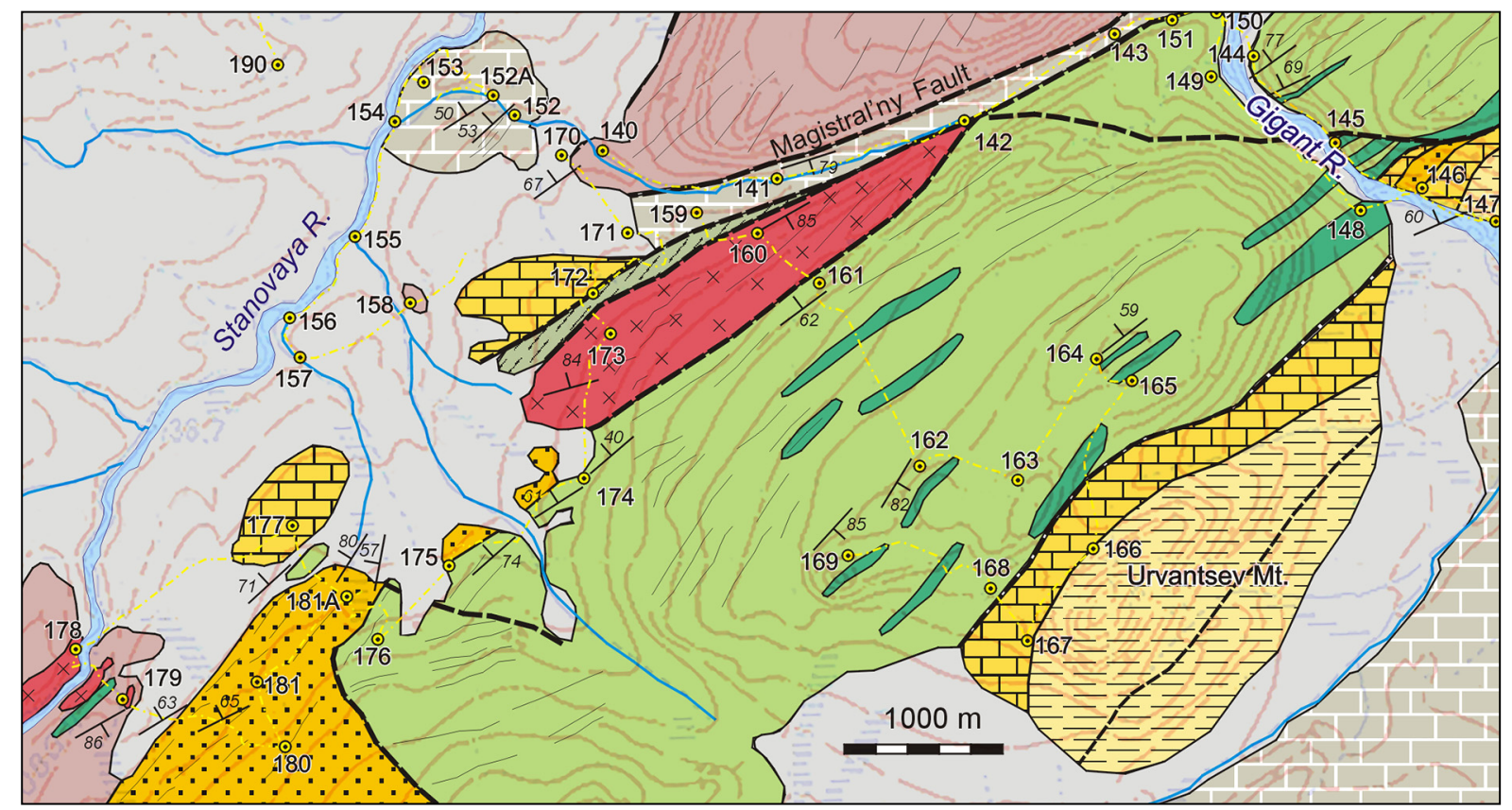

Fig. 5. Geological map illustrating the structural positions of granitic bodies in the upper reaches of the Stanovaya River. Red - granites ( $\sim 840 \mathrm{Ma}$ ); deep green - Neoproterozoic amphibolites. See Fig. 3 for other symbols.

Рис. 5. Геологическая карта, иллюстрирующая структурное положение гранитных тел в верховьях р. Становой. Красным цветом показаны граниты ( 840 млн лет), густо-зеленым цветом - неопротерозойские амфиболиты. Остальные условные обозначения см. на рисунке 3.

sites they resemble sheared porphyry. However the bulk of rocks can be rather described as mylonites or blastomylonites. Their volcanic protolith is quite probable: obvious meta-sedimentary rocks are absent in the succession; the chemical composition of the prevailing varieties is homogeneous; the zircon crystals extracted from one of samples show igneous origin and belong to a single age population $(840 \pm 4 \mathrm{Ma}$, unpublished data of the authors). There are numerous amphibolite bodies within felsic metavolcanics, which may be interpreted as metabasalts.

In the southeast and southwest, the volcanic rocks are in contact with the mid-Neoproterozoic rocks of the Stanovaya-Kolosova Group. On the slopes facing the Stanovaya River, the lower horizons of the Group were mapped earlier as the Urvantsev Fm. by [Stepanov et al., 1965]. These are green schists with small (1-2 mm) red microcline porphyroblasts and quartz gravel. On some sites, these rocks are replaced by arkose or quartz gritstones. The higher horizons of the Group exposed on the opposite side of the area shown in Fig. 5 comprise conglomerates, limestones, dolomites (including stromatolitic ones) and quartzites. Grey schists composing the upper horizons of the group are observed on the Urvantsev Mountain. Two granitic bodies named as Stepanov (lower left corner in Fig. 5) and Magistral'ny (in the midde of Fig 5) massifs are discussed below.

\subsection{STEPANOV MASSIF}

This small granite body was selected for detailed study as it was presumable intrude the Urvantsev Fm. [Stepanov et al., 1965], and so its geological position seemed similar to that of Pregradnaya massif. The Stepanov massif is well exposed on the left bank of the Stanovaya River (Fig. 6, a). There a deformed porphyritic granite with gneissic structure crops out (Fig. 6, $b$ ). Some varieties with rounded alkali feldspar resemble an augen gneiss. Feldspar phenocrysts may be a dominating mineral phase (Fig. 6,c).

The exposures continue on the right bank of the Stanovaya River (Fig. 6, d), where cataclased gneissic granites also crop out. There they stronger altered and associate with amphibolites and green schists. Further on (\# 179 in Fig. 5; a scarp visible in Fig. 6, $d$, in the midst of the left half of the picture), there is a rocky exposure of dolomite marble cut with numerous sills and dikes of porphyritic granite (Fig. $6, e$ ). Some of them are strongly budinaged (Fig. 6, $f$ ) due to plasticity of the host carbonate media. Granites are cataclased, carbonatized and pyritized.

\subsection{MAGISTRAL'NY MASSIF}

The massif crops out in lower scarps of terraced slope (\# 160 in Fig. 5 and Fig. 7, a). In most exposures 

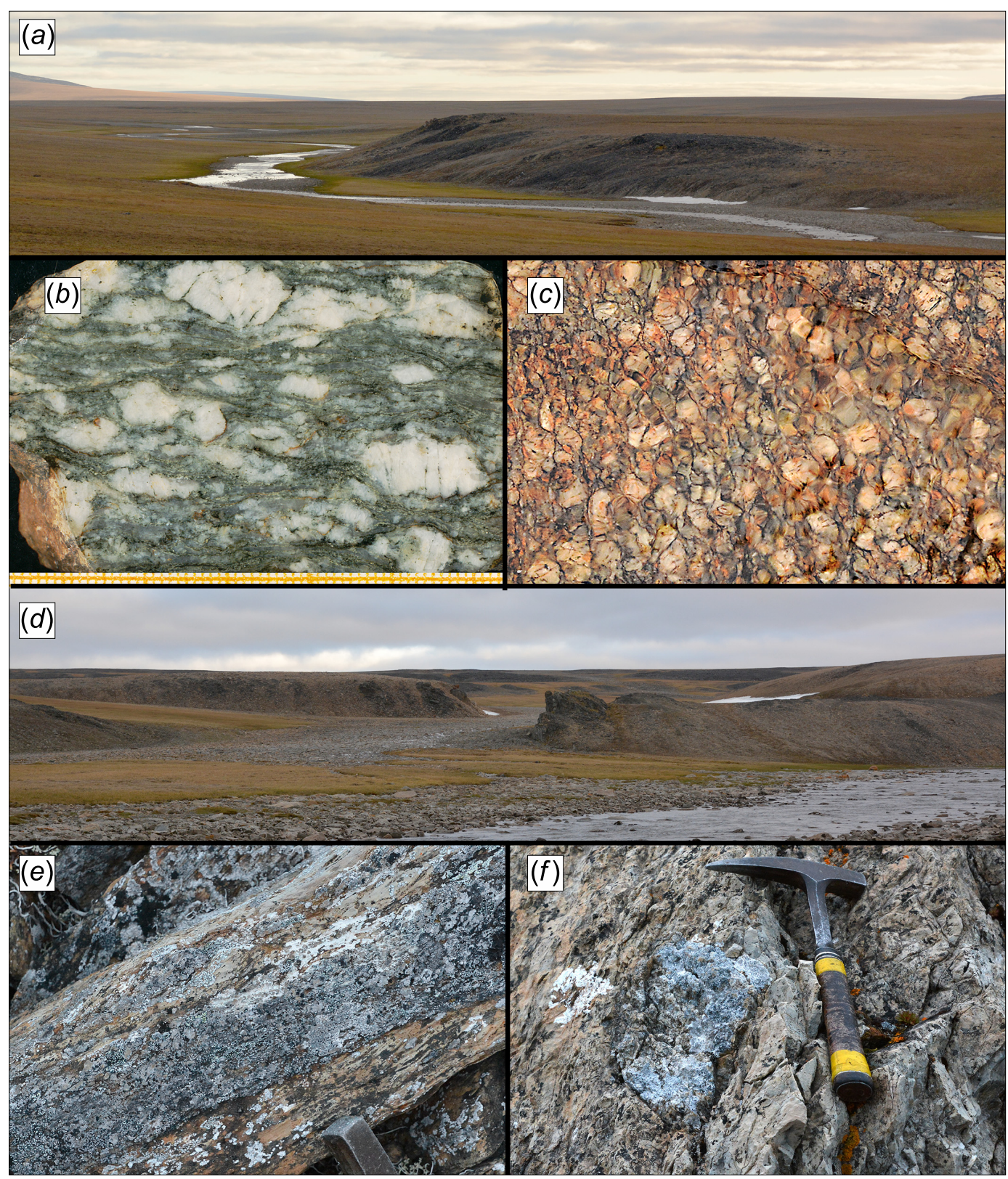

Fig. 6. Stepanov granite massif.

(a) - general view of the gneissic granite outcrop on the left bank of the Stanovaya River (site 178, see Fig. 5). (b) - scanned image of the cut surface of a typical granite sample from the outcrop (sample 178/1). The rock is cataclased and schistose. Only the alkali feldspar shows distinct contours; quartz composes vague veins and lenses, conformable with the general schistosity; plagioclase and biotite are transformed into foliated epidote-chlorite-sericite aggregate. Millimeter paper at the bottom of the photo for scale. (c) - porphyritic granite block below the water surface. It is almost entirely composed of potassium feldspar phenocrysts. $(d)$ - view from site 178 on the right bank of the Stanovaya River. Ridge in the foreground (right half of the picture) composed of altered gneissic granites, amphibolites and schists. The next ridge in the left half is made of marble penetrated by granite veins (site 179). Green schists and gritstones of the Urvantsev Fm. crop out in background(see Fig. 5). (e) - porphyritic granite vein (bluish-grey) in marble of the Zhdanov formation. Dated sample 179/2-16 was taken from a similar vein. $(f)$ - granite boudin in massive dolomite marble.

\section{Рис. 6. Фотографии гранитов Степановского массива.}

$(a)$ - общий вид обнажения гнейсогранитов на левом берегу р. Становой (т.н. 178, см. рис. 5). (b) - скан поверхности распила типичного гранита этого обнажения (обр. 178/1). Порода катаклазирована и рассланцована. Оформленные контуры сохранились только у кристаллов щелочного полевого шпата, кварц слагает жилки и линзочки, согласные с общим рассланцеванием, плагиоклаз и биотит превращены в рассланцованный эпидот-хлорит-серицитовый агрегат. Миллиметровка в нижней части фото для масштаба. $(c)$ - глыба порфировидного гранита, почти полностью состоящая из фенокристов КПШ. $(d)$ - вид с точки 178 на обнажения правого берега р. Становой. Скалки на ближнем плане справа сложены сильно измененными гранитогнейсами, амфиболитами и сланцами. Скальные выходы в левой половине фотографии - обнажения мраморов (т.н. 179) с жилами гнейсогранитов. На дальнем плане - гряды зеленых сланцев и гравелитов «урванцевской свиты» (см. рис. 5). (e) - жила порфировидных гранитов (серое) среди рассланцованных мраморов ждановской толщи. Из подобной жилы отобран продатированный образец 179/2-16. (f) - гранитная будина в массивных доломитовых мраморах. 


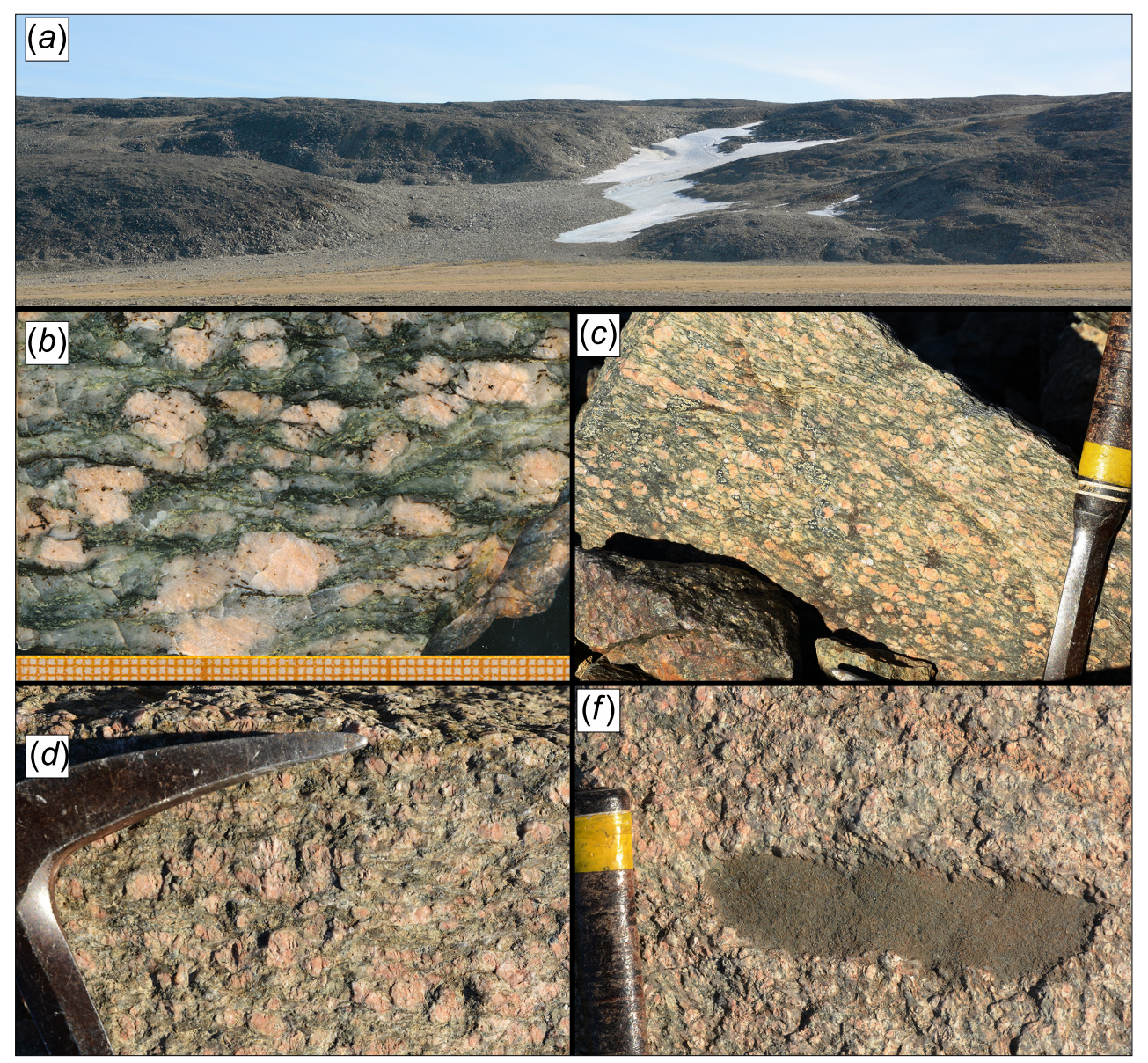

Fig. 7. The Magistral'ny granite.

(a) - scarps and cryoplanation terraces composed of gneissic granites. At the foot of the slope on the left is site 160 (see Fig. 5). (b) - texture of gneissic granite from the lower ledge (sample 160/2, see text). Millimeter paper is at the bottom. (c) - gneissic granite in the lower scarp. The matrix was mylonitized, and the original granite texture is completely lost. $(d)$ - augen gneissic granite. The rock is less foliated and contains plagioclase remnants. $(e)$ - xenolith in granite. The original granitic texture is partly preserved.

Рис. 7. Граниты Магистрального массива.

(a) - вид на уступы (нагорные террасы), сложенные разгнейсованными гранитами. У подножия склона слева - точка 160 (см. рис. 5). (b) - структура гнейсогранитов нижнего уступа на распиле (обр. 160/2) (описана в тексте). Внизу - миллиметровка для масштаба. (c) - сильно рассланцеванный гнейсогранит первого уступа с милонитизированным матриксом, полностью утратившим гранитную структуру. $(d)$ - очковый гнейсогранит в первом уступе. Порода менее рассланцована, и в ней угадываются реликты кристаллов плагиоклаза. $(e)$ - ксенолит в граните. Видна сравнительно слабо измененная гранитная структура субстрата.

granites look like metasomatic rocks with K-feldspar porphyroblasts. Such metasomatism is actually observed at the NW margin of the massif at the foot of slope, where sericite-chlorite green schists contain scattered large $(1-3 \mathrm{~cm})$ feldspar porphyroblasts.

The granitic body proper is composed of augen gneissic granite. The rock contains rounded and shapeless, rarely idiomorphic crystals (to $1.5 \mathrm{~cm}$ ) of pink perthitic feldspar in the schistose matrix. The latter composed of quartz lenses with inclusions of albite, and scabby zoisite-sericite aggregate. This aggregate replaces plagioclase, as evidenced by blurred polysynthetic twinning in some samples. Dark bands and lenses are composed of chlorite and biotite.
In the vicinity of the 160 point (see Fig. 5, Fig 7, a) structure of rocks is clearly visible in the fresh-cut blocks and walls. In the lower part of the slope, the rocks often demonstrate cataclasis and dynamic recrystallization of quartz and K-feldspar to form elongate and lenticular segregations (Fig. 7, $b, c$ ) immersed into sericite and chlorite-epidote-sericite aggregate. Higher on the slope occur less sheared rocks with rounded phenocrysts (Fig. 7, d). In the same part of the massif even less altered varieties can be found, which preserve remnants of granite structure, and contours of tabular crystals of plagioclase are clearly visible. Presence of xenoliths in this part of the massif (Fig. 7,e) give unequivocal evidence that this is an igneous rock crystallized from magma. We as- 
sume that the augen gneisses of the lower scarp also crystallized as granites, but were sheared afterwards.

\section{ChEMical COMPOSITION}

All the analyzed rocks (Table 1) are the most common potassium granites with concentrations (dry composition, wt. \%) of: silica 71-75, alumina 13-16, alkalis 7.2-8.7, and $\mathrm{K}_{2} \mathrm{O} / \mathrm{Na}_{2} \mathrm{O}=1.0-1.7$ (in one case - 0.4). All granites are weakly peraluminous. The alumina saturation index is 1.05-1.20, except one analysis (0.99). In the geochemical classification scheme of granitic rocks [Frost et al., 2001; Frost B.R., Frost C.D., 2008], all the analyzed rocks are magnesian and can be further classified into calc-alkalic and alkali-calcic, with the exception of one analysis that is calcic.

The gross chemical compositions vary only slightly, and normalized concentrations of minor elements look homogeneous in the diagrams. The pattern of rare earth elements (REE) contents is the same for all samples and is generally typical for the most common varieties of granites: weakly fractionated heavy REE (around 10 chondritic values), stronger fractionated light REE (to 100 chondritic values), and insignificant negative europium anomaly (Fig. 8). Comparison with the Snezhnaya granites (shaded area in Fig. 8) shows that in the latter is somewhat higher REE content. The multi-element diagram shows the $\mathrm{Nb}$ and $\mathrm{Ti}$ negative anomalies inherited from the source and typical of crustal magmas. The $\mathrm{Sr}$ negative anomaly is generally attributed to plagioclase fractionation. Obviously, magma sources for all the analyzed granites were crustal rocks and, possibly, middlecrust rocks in the garnet stability zone, as evidenced by the relatively low concentrations of heavy REEs. According to the above data, the geochemical characteristics of the Pregradnaya, Stepanov and Magistral'ny massifs are quite similar and do not differ from those of the Snezhnaya complex described in [Proskurnin et al., 2014, and references therein]. However, the zircon dating shows that the Pregradnaya granite and the granites from the upper reaches of the Stanovaya River belong to different complexes.

\section{U-PB ISOTOPE ANALYSIS OF ZIRCONS}

Zircons were extracted from the granite samples by first two authors in the laboratory of GIN RAS. Isotopic analyses of $\mathrm{U}$, Th and $\mathrm{Pb}$ was carried out on a SHRIMPII mass spectrometer at VSEGEI, using a procedure similar to that described in [Williams, 1998]. Ion beam diameter was set to $\sim 25 \mu \mathrm{m}$; each spot scanned four times; ion countings was taken successively through range of masses in each scan. Temora-2 standard was used for calibration of $\mathrm{U} / \mathrm{Pb}$ isotopic ratios; standard
91500 to determine $\mathrm{U}$ and $\mathrm{Pb}$ concentrations; data were processed using SQUID and ISOPLOT software [Ludwig, 2001, 2003].

\subsection{SAMPle 045/1-16, Pregradnaya massif}

Zircon crystals are dark brown-coloured, euhedral without signs of dissolution or overgrowth; they are heavily fractured and contain numerous inclusions (Fig. 9). Large crystals are short-prismatic, among small ones, occur also long-prismatic to needle-shaped crystals. They have high U concentrations (to 1200 ppm) and look very dark in cathodoluminescent (CL) images. The magmatic oscillatory zoning is clearly visible in backscattered electron (BSE) images and even in optical images (see Fig. 9). Cores are usually recrystallized, often to a complete loss of the original structure. We analyzed 11 spots on 11 crystals. Zircons are characterized by a 'magmatic' Th/U ratio (Table 2). Almost all analyses contain substantial (some very high) proportion of common $\mathrm{Pb}$ (Table 2). This is partly due to specific properties of the $\mathrm{Pb}$-rich granite magma, as evidenced by the presence of galenite among heavy minerals. High common $\mathrm{Pb}$ concentrations in some analyses makes it impossible to adequately calculate a correction for common $\mathrm{Pb}$ by the standard model. In the conventional isotopic diagram $\left({ }^{207} \mathrm{~Pb} /{ }^{235} \mathrm{U}\right.$ vers. ${ }^{206} \mathrm{~Pb} /{ }^{238} \mathrm{U}$ ), six analyses became reversly discordant if apply a correction for common $\mathrm{Pb}$. The age of the concordant cluster calculated for the remaining five analyses is $607 \pm 2 \mathrm{Ma}(2 \mathrm{~s}$ ), and MSWD (of concordance) = 0.46 . The Tera-Wasserburg isotope diagram operating with total $\mathrm{Pb}$ (including common $\mathrm{Pb}$ ) is more useful for such data. It turned out that all 11 analyses can be approximated by a straight line with very good statistical parameters (Fig. 10). The lower interception with the concordia at a point of $609 \pm 2$ (2 sigma) million years indicates the time of zircon crystallization.

\subsection{SAMPLE 160/2-16, MAGISTRAL'NY MASSIF}

Zircons of this sample are quite different from Pregradnaya ones; they are cleaner, without cracks, the prism is not a square in section but closer to an octagon. The CL images show normal oscillatory zoning (Fig. 9). In many crystals, the inner part is more uniform and relatively light (i.e. lower U and REE concentrations), while the outer part is darker, with fine contrasting oscillatory zoning. Some crystals retained more or less explicit cores. The analyzed spots show moderate concentration of uranium (up to $500 \mathrm{ppm}$ ) and a 'magmatic' Th/U ratio (Table 2).

Ten spots on nine crystals were set mostly on the external oscillatory zone, which usually occupies most of a crystal. The central part was also analized for one crystal and yielded a similar age. All the 10 analyses 
$\mathrm{T}$ a b l e 1. Chemical compositions of granites (major oxides in wt. \%; trace elements in ppm)

Т а б л и ц а 1. Химический состав гранитов. Породообразующе окислы в мас. \%, малые элементы в ррт

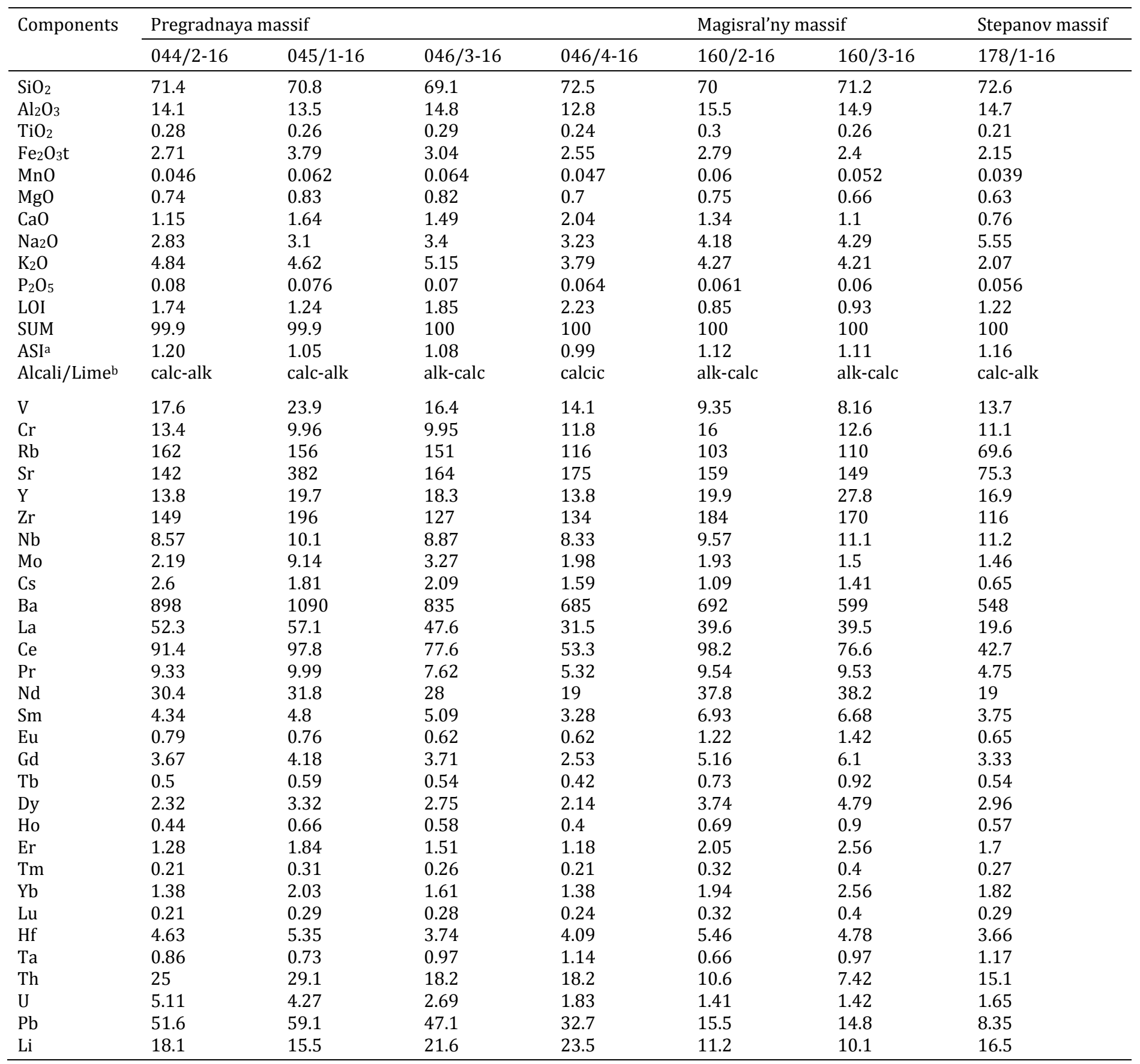

$\mathrm{N}$ o t e. Analyzed at VSEGEI: major oxides by XRF, trace elements by ICP MS, Li and Pb by ICP-AES. a - Alumina Saturation Index $=$ molar $\mathrm{Al}_{2} \mathrm{O}_{3} /\left(\left(\mathrm{CaO}-3.33 \mathrm{P}_{2} \mathrm{O}_{5}\right)+\mathrm{Na}_{2} \mathrm{O}+\mathrm{K}_{2} \mathrm{O}\right)$. b - after [Frost et al., 2001; Frost B.R., Frost C.D., 2008].

П р и м е ч а н и е. Анализы выполнены в ВСЕГЕИ: основные оксиды по XRF, микроэлементы по ICP MS, Li и Pb по ICP-AES. а - индекс насыщения оксида алюминия = молярный $\mathrm{Al}_{2} \mathrm{O}_{3} /\left(\left(\mathrm{CaO}-3.33 \mathrm{P}_{2} \mathrm{O}_{5}\right)+\mathrm{Na}_{2} \mathrm{O}+\mathrm{K}_{2} \mathrm{O}\right)$. b - согласно [Frost et al., 2001; Frost B.R., Frost C.D., 2008].

form a concordant cluster with age of $843 \pm 6 \mathrm{Ma}$ (Fig. 10).

\subsection{SAMPLE 179/2-16, STEPANOV MASSIF}

Zircons from this sample are very similar in every respect to those from the Magistral'ny massif (see Fig. 9), some crystals exhibit indistinct cores. In the CL images the central part usually is lighter with rough zoning, while the outer part is darker, with finer oscillatory zoning. In some zircons, there is one more relatively bright zone between the above two. The $U$ concentrations and $\mathrm{Th} / \mathrm{U}$ ratios are approximately similar to those of sample 160/2-16 (Table 2). Central and marginal 
A.B. Kuzmichev et al.: The pre-Vendian (640-610 Ma) granite magmatism in the Central Taimyr fold belt...
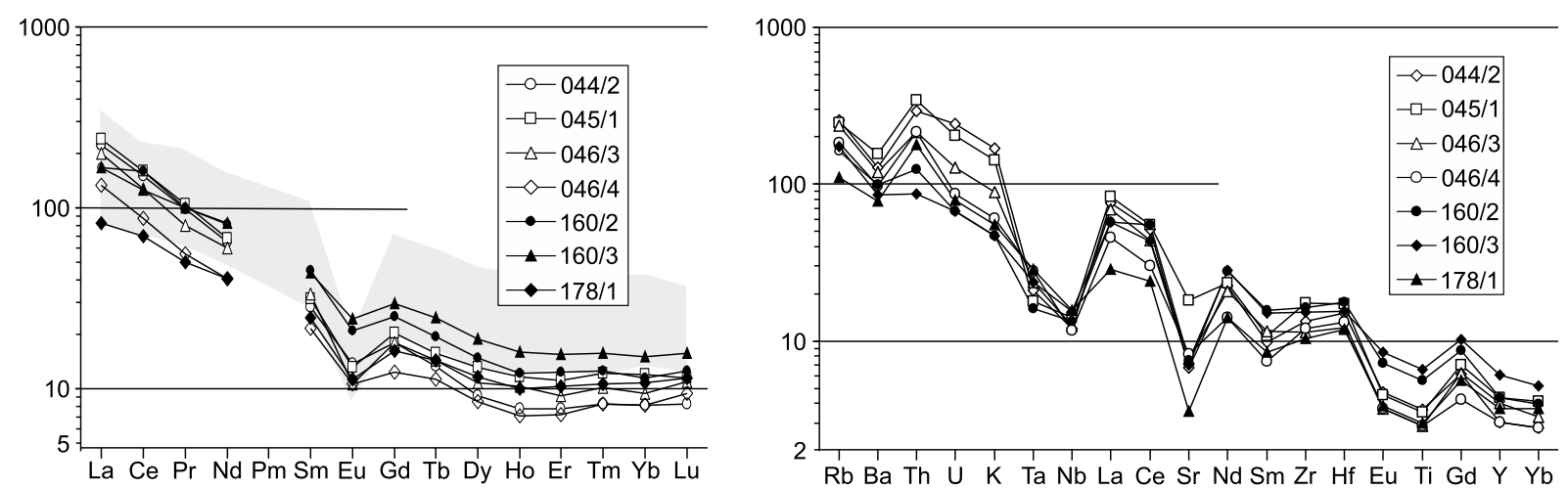

Fig. 8. Trace element diagrams: chondrite-normalized REE concentrations on the left; 'incompatible' elements normalized to primitive mantle on the right. Compositions of chondrite and primitive mantle after [Sun, McDonough, 1989]. Shaded contour on the REE graph - Snezhnaya granitic complex at the upper reaches of the Leningradskaya River [Proskurnin et al., 2014].

Рис. 8. Графики распределения малых элементов. Слева - концентрации РЗЭ, нормированные по хондриту, справа мультиэлементный график концентраций «несовместимых элементов» нормированных по примитивной мантии. Состав хондрита и примитивной мантии по [Sun, McDonough, 1989]. Затемненный контур на графике РЗЭ - гранитоиды снежнинского комплекса верховьев р. Ленинградской по [Proskurnin et al., 2014].

parts of the crystals were tested, and all the three zones were analyzed for one crystal. In total, nine analyses were performed for five crystals, and all the CL zones have returned the same age. Eight analyses form a clus- ter with age of $840 \pm 5 \mathrm{Ma}$ (Fig. 10), which coincides with the age of Magistralny massif within the errors. One analysis on the rim gave $\sim 810 \mathrm{Ma}$ probably due to $\mathrm{Pb}$ loss during late Neoproterozoic thermal impact.

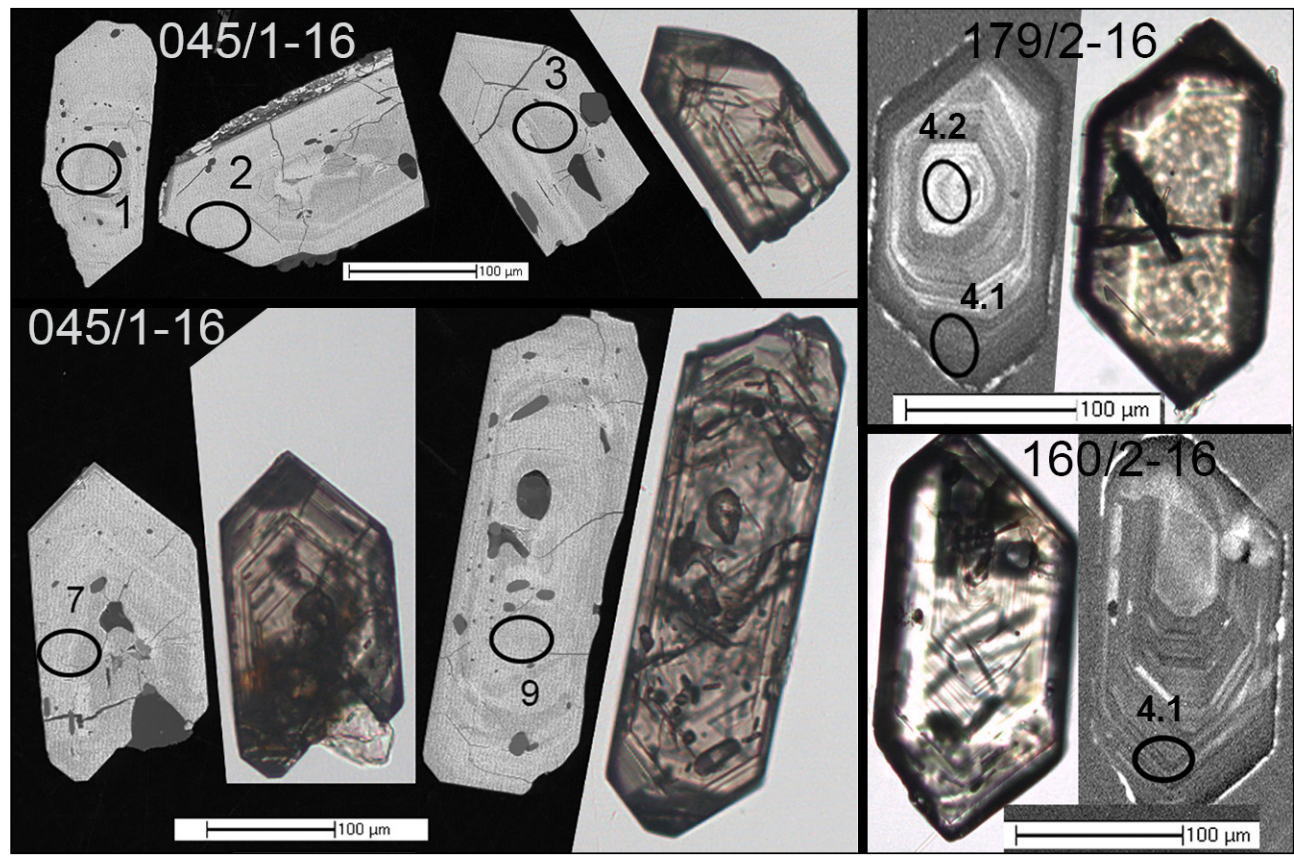

Fig. 9. Examples of the analyzed zircon crystals imaged in transmitted light, backscattering electrons (sample 045/1-16) and cathodoluminescence (samples 179/2-16 and 160/2-16). Left - Pregradnaya granite (045/1-16; upper right - Stepanov granite (179/2-16); lower right - Magistral'ny granite (160/2-16). The spot numbers are labeled.

Рис. 9. Изображения проанализированных кристаллов циркона, выполненные в проходящем свете, в режиме обратно-рассеянных электронов (для образца 045/1-16) и катодолюминесценции. Левая панель - Преградненский массив (045/1-16), правая верхняя панель - Степановский массив (179/2-16), правая нижняя панель - Магистральный массив (160/2-16). Подписаны номера проанализированных точек, соответствующие таблице 2. 


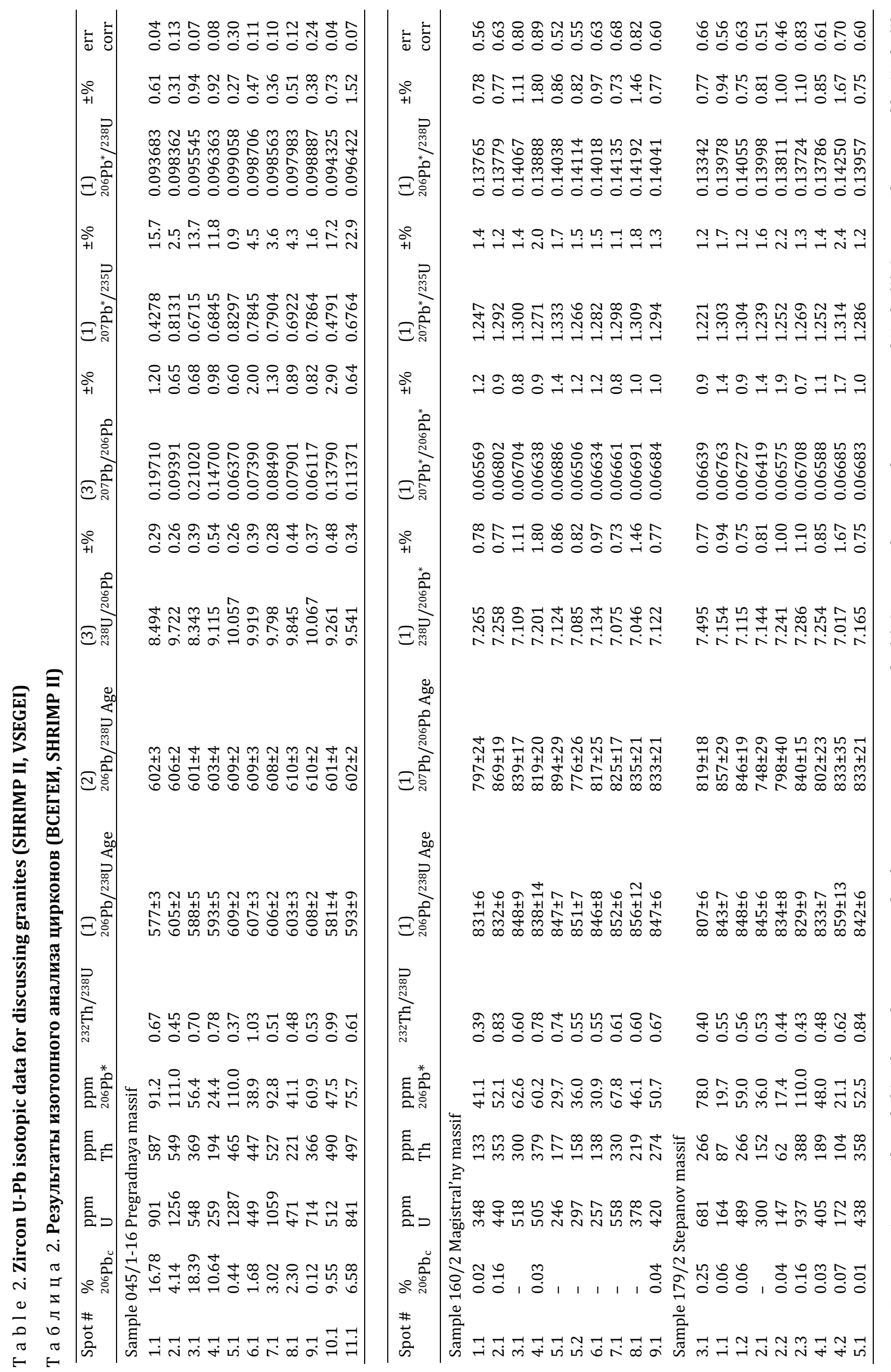

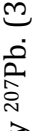

芑思 ญํ

运㻤

焉嵒

온

곰

(1)

준

窇

要

ปิ

宓

逢

준

당

要

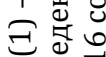

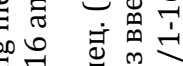

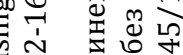

न 10

च⿱艹

造守

ํ.

웅

ह

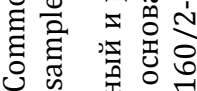

西要

通

กิ

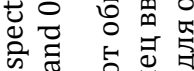

范

ज苗

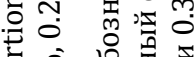

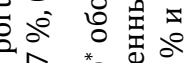

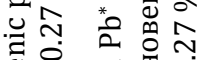

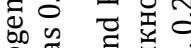

西

đั

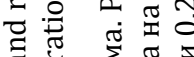

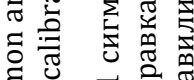

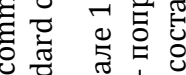

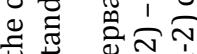

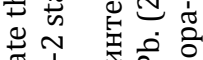

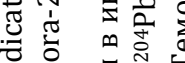

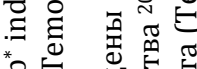

$*$

흐 흠

을

论

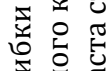

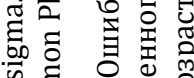

फै ह

0 : 5

क

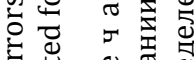

壳要

论 200 

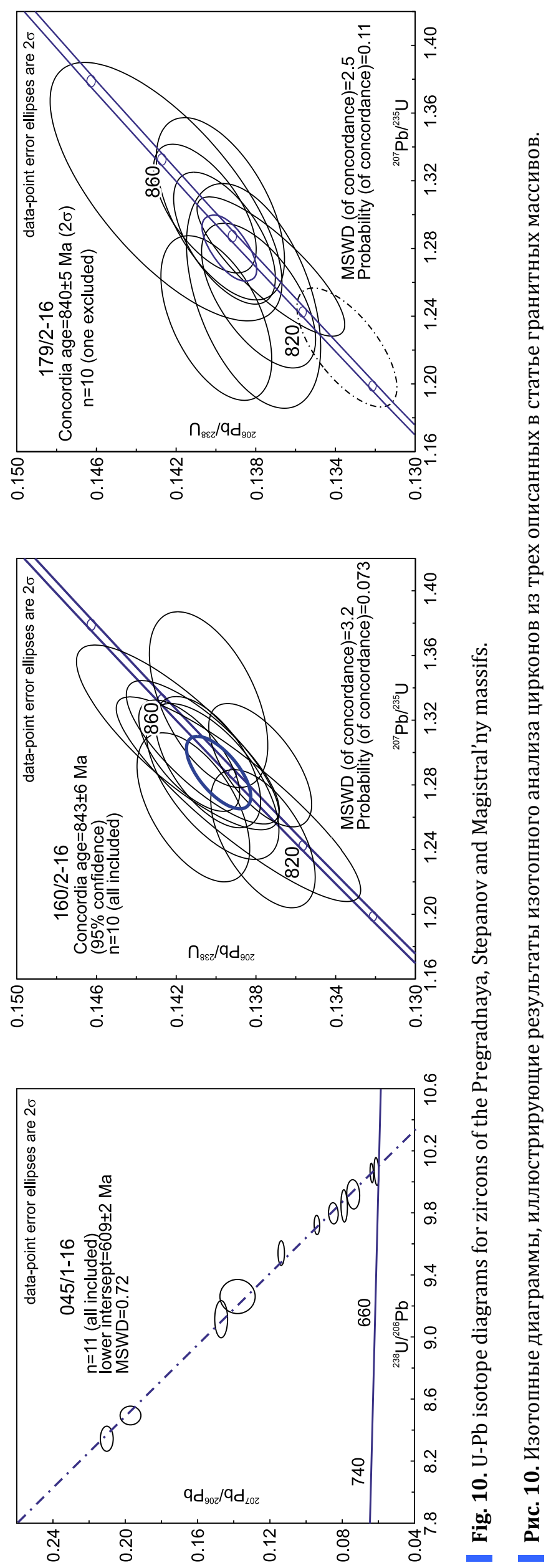

\section{DisCUSSION}

\subsection{ClASSIFICATION OF THE GRANITIC ROCKS AND MAGMA SOURCES}

It seems reasonable in this section to indicate the type of granite our massifs belong to. Among the proposed classifications of granitoids (see the review in [Barbarin, 1990; Frost et al., 2001]), the most popular (at least in Russia) is the 'alphabetic' one, in which granitoids are tried to be related to one of the three most common types (I, S or A) according to recommendations in [Whalen et al., 1987; Chappel, White, 2001]. Granites can be readily discriminated in case of clearly manifested characteristic features, but the most common granites, including three massifs discussing in the paper, do not demonstrate such features. In our study, the following characteristics of the analyzed granites are symptomatic: (i) homogeneous composition with a narrow range of $\mathrm{SiO}_{2}$ variations (70-75 wt. \%); (ii) weaklyperaluminous composition (ASI=1.0-1.2) and potassium specialization of most varieties; (iii) absence of differentiates of dioritic and gabbroic compositions, at least, in obvious relation to granites. These characteristics are valid for described massifs and for other rather large plutons of the Snezhnaya complex, which we observed later in the Peka and Faddey river valleys (to the north of area shown in Fig. 2) as well. Such granites are close to the S-type (e.g., [Pearce at al., 1984; Chappell, White, 2001; Frost et al., 2001; Frost B.R., Frost C.D., 2008], and references therein), however, they differ from high-alumina muscovite granites typical for the S-type.

Anatexis of Mesoproterozoic meta-sedimentary rocks we observed at many points (see Fig. 2), and apparently these rocks were the main source of magma of the studied intrusions. Dating of leucosome of migmatites and related granitic veins (unpublished data of the authors) shows that among them there are rocks of the same ages as both discussed granite complexes.

\subsection{GEODYNAMIC SETTING OF GRANITES}

Plutons similar to the studied granite massifs can be emplaced into the upper crust in different geodynamic settings such as an active continental margin, a continent-continent or continent-island arc collision, postcollisional extension, and even within-plate ([Moyen et al., 2017], and references therein). It is impossible to distinguish those settings solely on the basis of chemical analyses of rocks, without additional geological information.

The following data should be taken into account. Dating of zircons from migmatite leukosome and leucogranite veins yields a range of ages from 980 to $800 \mathrm{Ma}$, with the most intense peak at 850-840 Ma ([Kuzmichev, Danukalova, 2018], and unpublished data of the authors). The protracted anatexis we associate with the 
setting of an active continental margin, which is partially confirmed by the dating of volcanic rocks. The age range of the Snezhnaya granites is much narrower, 845-825 Ma. Obviously, melted materials from the depths did not always reach the upper crust, and extensive granite emplacement at the end of the first half of the Neoproterozoic was related to a discrete event. In our assumption, it was a collision event, which entail orogeny and subsequent deposition of the Stanovaya clastic rocks. In the course of the orogeny the Snezhnaya granites were exhumed and eroded, which is registered in the ages of detrital zircons [Priyatkina et al., 2017]. Since the main characterstic features of Pregradnaya complex are similar to the Snezhnaya ones, the same conclusions are valid for both in terms of the geodynamic setting, although the scale of the last collision event was probably lower. The final stage of the Precambrian granite magmatism was also accompanied by orogeny. The synorogenic clastic rocks (Chekin Fm.) are known on the Chelyuskin Peninsula (see below).

\subsection{OCCURENCE OF LATE NEOPROTEROZOIC GRANITIC ROCKS IN TAIMYR}

The Pregradnaya massif is not the only evidence of the pre-Vendian crustal rocks fusion and granite emplacement. According to the authors' preliminary results, migmatites of close ages are found in the cape facing the north, located between the mouths of the Stanovaya and Gorodkova rivers (Fig. 2). The ages of almost half (48 spots) of zircon grains analyzed by LA ICPMS technique are in the range of 600-660 Ma with a peak value of 630 million years. Zircons with multistage overgrowth rims and old cores are challenging objects for laser ablation since material from several zones of different ages gets into the analysis. The data should be confirmed by the SIMS method with separate dating of the each zone. Perhaps here we met a root zone of the late Neoproterozoic granites.

Another granite pluton, located to the north of the Fig. 2 frame and studied later, may also be of the same age as the Pregradnaya massif. Among heavy minerals separated along with zircon (not dated yet) there was galenite, which is a typical feature of the Pregradnaya granite.

Further to the northeast, in the Zimovochnaya Bay area there is one more granite massif with the zircon SIMS age of $\sim 630 \mathrm{Ma}$ [Pease, Vernikovsky, 2000]. It is embedded into metamorphic rocks comparable to those in the study area and composed of deformed two-mica granite. The zircons contain early Neoproterozoic cores and show complex zoning.

Several late Neoproterozoic granite massifs (Nansen complex) are mapped approx. $30 \mathrm{~km}$ north of the Leningradskaya river mouth (see oval in Fig. 1). Three zircon samples from different massifs were analyzed using ID
TIMS technique (Paderin et al., unpublished data). The results are not very reliable due to large errors that are not typical of the method. In total, eight analyses were done, and seven of eight were discordant due to $\mathrm{Pb}$ loss. They show different ${ }^{207} \mathrm{~Pb} / 206 \mathrm{~Pb}$ values and apparently do not belong to the same-age suite. One sub-concordant analysis yielded a 'concordant' age of $636.6 \pm 1.1 \mathrm{Ma}$. According to [Makariev, 2013], these massifs belong to the Chukcha complex, and the SHRIMP dating (10 spots per sample) of two granite samples from the bank of Gafner Fjord (bottom part of the oval in Fig. 1) yields $640 \pm 3 \mathrm{Ma}$ and $635 \pm 8 \mathrm{Ma}$. In general, this means that the pre-Vendian granites are more abundant in the northeastern part of the Central Taimyr belt rather than in the territory covered by our study.

\subsection{TAIMYR TECTONICS IN THE NEOPROTEROZOIC}

Our study confirms two orogenic events in the Neoproterozoic evolution of the Central Taimyr belt (e.g., [Vernikovsky, 1996; Vernikovsky, Vernikovskaya, 2001]) and we assume that both events were related to collisions. The first one was manifested by emplacement of the Snezhnaya granites with the age of 845-825 Ma. The collision could have started earlier than $845 \mathrm{Ma}$ and finished earlier then $825 \mathrm{Ma}$ as the most of Snezhnaya plutons are discordant, i.e. late- or post-collisional ones. On the other hand, orogeny could lasted more long. The youngest zircons from migmatites and granite veins in studied area have shown the age of 780770 Ma [Kuzmichev Danukalova, 2018]. This is the age of the youngest metamorphic rims, which usually do not constitute a distinct cluster in isotope diagram, but distributed along concordia line. The youngest ages correspond to final stages of a long period of repeated dissolution and overgrowth of zircons and these final stages may include $\mathrm{Pb}$ loss due to late Neoproterozoic thermal effect, when regime of active margin in the northern Central Taimyr belt was reestablished. Under such uncertainty we tentatively assign termination of early Neoproterozoic orogeny to $800 \mathrm{Ma}$, that is to the date more confidently proved by isotopic analyses.

V.A. Vernikovsky relates mid-Neoproterozoic orogeny to 'accretion - collision' processes that formed the Central Taimyr microcontinent [Vernikovsky, 1996; Vernikovsky, Vernikovskaya, 2001; Proskurnin et al., 2014]. We, however believe that a substantial part of the Central Taimyr belt area belonged to the Siberian craton at least from Mesoproterozoic, and the 'accretion - collision' processes could have developed only along the northern margin of the belt [Priyatkina et al., 2017; Kuzmichev, Danukalova, 2018].

In the second half of the Neoproterozoic, magmatism was predominantly active in the northern and northeastern parts of the modern Central Taimyr belt, wherein suprasubduction volcanic rocks of the late $\mathrm{Ne}$ - 
oproterozoic age are widespread. Their isotopic ages that are summarized in [Makariev, 2013] are in the range of 760-610 Ma. According to published data [Markovsky et al., 2000; Makariev, 2013] these suprasubduction volcanic rocks unconformably lie on the Zhdanova and Kolosova formations. As shown above, the first formation is Mesoproterozoic in age, the second is mid-Neoproterozoic, and both were formed within bounds of the Siberian craton. This means that if the indicated correlations with the Zhdanova and Kolosova Formations are correct, then in the late Neoproterozoic, the NE part of the Central Taimyr belt was also a part of the Siberian paleocontinent. The presence of differentiated (basalt-andesite-rhyolite) suprasubduction volcanics indicates the active margin regime in the second half of the Neoproterozoic that was concluded by collision event in Vendian.

The synorogenic clastic deposits of this stage are preserved only in the NE part of the Central Taimyr belt. These are variegated clastic deposits of about 900 m-thick composed mostly of fragmented volcanic rocks mentioned in the previous paragraph [Makariev, 2013]. The Vendian orogen was completely peneplained by the beginning of Paleozoic, when Siberian Platform covered the entire Central Taimyr belt [Sobolevskaya, Kaban'kov, 2014].

The question of possible involvement of the Central Taimyr belt into Vendian collision event was initiated by V.A. Vernikovsky ([Vernikovsky, 1996] and his subsequent publications] and discussed in [Priyatkina et al., 2017, p. 1650] The issue is important for understanding the tectonic evolution of the Siberian craton and its probable collision with the Baltica. The currently available information is still insufficient and it is unknown what continent or microcontinent the Siberian craton was came upon.

\section{CONCLUSIONS}

1. The granite pluton (Pregradnaya massif) that intruded the mid-Neoproterozoic orogenic deposits of Stanovaya-Kolosova Group was discovered in the SE part of the Central Taimyr belt. This finding was unex- pected as these orogenic deposits are known to contain pebbles and boulders of similar porphyritic granites attributed to the Sneznaya complex (845-825 Ma). As it turned out the U-Pb zircon age (SHRIMP) of the Pregradnaya granites amounted to $609 \pm 2 \mathrm{Ma}$, which is quite uncommon for the belt.

2. The Pregradnaya massif and several other granitic bodies with similar textural and geochemical features, are located within deformation zone in the SE part of the Central Taimyr belt. Their position seemed to be consistent with the idea by V.A. Vernikovsky that the 'accretionary belt' collided with the Siberian paleocontinent in Vendian or pre-Vendian times. However, other granite massifs in this deformation zone turned out to be older, belonging to the Snezhnaya (845-825 Ma) complex. According to published data, the late Neoproterozoic granites (640-610 Ma) are more abundant in the northern part of the belt, and are not confined to its southeastern margin.

3. The petrological and geochemical similarities between the Snezhnaya and Pregradnaya granites (845$825 \mathrm{Ma}$ and 640-610 Ma, respectively) indicate that they were produced from similar melt sources in presumably similar conditions $\left(\mathrm{P}, \mathrm{T}, \mathrm{H}_{2} \mathrm{O}\right)$. We suggest that the two granite magmatism 'flare-ups' separated by an interval of $200 \mathrm{Ma}$ were related to two collision events that took place along the Taimyrian margin of the Siberian paleocontinent. The first event resulted in the massive intrusions of granite batholiths and the formation of a full-scale long-term orogeny. Its erosion products are widespread in the Central Taimyr belt. The second event was a more modest one. It is not known what terranes collided with Siberia during these events.

\section{ACKNOWLEDGEMENTS}

We are grateful to A.N. Larionov for the isotopic dating of zircons. Our studies were supported by the Russian Foundation for Basic Research (Grants 16-0500176 and 19-05-00926). The study of A.B. Kuzmichev and M.K. Danukalova was part of the GIN RAS Research Programme (No. 0135-2019-0051).

\section{REFERENCES}

Barbarin B., 1990. Granitoids: main petrogenetic classifications in relation to origin and tectonic setting. Geological Journal 25 (3-4), 227-238. https://doi.org/10.1002/gj.3350250306.

Bezzubtsev V.V., Zalyaleev R.Sh., Goncharov Yu.I., Sakovich A.B., 1983. Geological Map of Mountainous Taimyr. Scale 1:500000. Krasnoyarsk. 6 sheets (in Russian) [Беззубцев В.В., Залялеев Р.Ш., Гончаров Ю.И., Сакович А.Б. Геологическая карта Горного Таймыра. Масштаб 1:500000. Красноярск, 1983. 6 л.].

Bezzubtsev V.V., Zalyaleev R.Sh., Sakovich A.B., 1986. Geological Map of Mountainous Taimyr. Scale 1:500000. Explanatory note. Krasnoyarsk, 177 p. (in Russian) [Беззубцев В.В., Залялеев Р.Ш., Сакович А.Б. Геологическая карта Горного Таймыра. Масштаб 1:500000. Объяснительная записка. Красноярск, 1986. 177 с.]. 
Chappell B.W., White A.J.R., 2001. Two contrasting granite types: 25 years later. Australian Journal of Earth Sciences 48 (4), 489-499. https://doi.org/10.1046/j.1440-0952.2001.00882.x.

Frost B.R., Barnes C.G., Collins W.J., Arculus R.J., Ellis D.J., Frost C.D., 2001. A geochemical classification for granitic rocks. Journal of Petrology 42 (11), 2033-2048. https://doi.org/10.1093/petrology/42.11.2033

Frost B.R., Frost C.D., 2008. A geochemical classification for feldspathic igneous rocks. Journal of Petrology 49 (11), 1955-1969. https://doi.org/10.1093/petrology/egn054.

Kuzmichev A.B., Danukalova M.K., 2018. The Central Taimyr fold belt in the Precambrian: passive margin of the Siberian paleocontinent in the Mesoproterozoic and active margin in the Neoproterozoic. In: Problems of tectonics and geodynamics of the Earth's crust and mantle. Proceedings of 50th tectonic meeting. Vol. 1. GEOS, Moscow, p. 352-356 (in Russian) [Кузьмичев А.Б., Данукалова М.К. Центрально-Таймырский складчатый пояс в докембрии: пассивная окраина Сибирского палеоконтинента в мезопротерозое, активная окраина в неопротерозое // Проблемы тектоники и геодинамики земной коры и мантии: Материалы L Тектонического совещания. Т. 1. М.: ГЕОС, 2018. С. 352-356].

Ludwig K.R., 2001. Squid 1.02. A Geochronological Toolkit for Microsoft Excel. Berkeley Geochronology Center Special Publication, vol. 2, 19 p.

Ludwig K.R., 2003. Isoplot 3.00. A Geochronological Toolkit for Microsoft Excel. Berkeley Geochronology Center Special Publication, vol. 4, 77 p.

Makariev A.A. (Ed.), 2013. State Geological Map of the Russian Federation. Scale 1:1000000 (third generation). Sheet T-45-48 (Chelyuskin Peninsula). Explanatory note. VSEGEI Cartographic Factory, Saint Petersburg, 472 p. (in Russian) [Государственная геологическая карта Российской Федерации. Масштаб 1:1000000 (третье поколение). Лист Т-45-48 (м. Челюскин). Объяснительная записка / Ред. А.А. Макарьев. СПб.: Картфабрика ВСЕГЕИ, 2013. 472 с.].

Markovsky V.A., Kaban'kov V.Ya., Sobolevskaya R.F., Proskurnin V.F., Shneider G.V., Lazareva L.N., Gavrilov A.G., 2000. State Geological Map of the Russian Federation. Scale 1:200000. Taimyr. Sheets T-47-XXVIII-XXX, T-48-XIX-XXX. Explanatory note. Moscow, 186 p. (in Russian] [Марковский В.А., Кабаньков В.Я., Соболевская Р.Ф., Проскурнин В.Ф., Шнейдер Г.В., Лазарева Л.Н., Гаврилов А.Г. Государственная геологическая карта Российской Федерации. Масштаб 1:200000. Серия Таймырская. Листы: T-47-XXVIII-XXX, T-48-XIX-XXX. Объяснительная записка. М., 2000. 186 с.].

Moyen J.F., Laurent O., Chelle-Michou C., Couzinié S., Vanderhaeghe O., Zeh A., Villaros A., Gardien V., 2017. Collision vs. subduction-related magmatism: two contrasting ways of granite formation and implications for crustal growth. Lithos 277, 154-177. https://doi.org/10.1016/j.lithos.2016.09.018.

Pearce J.A., Harris N.B.W., Tindle A.G., 1984. Trace element discrimination diagrams for the tectonic interpretation of granitic rocks. Journal of Petrology 25 (4), 956-983. https://doi.org/10.1093/petrology/25.4.956.

Pease V., Vernikovsky V., 2000. The tectono-magmatic evolution of the Taimyr Peninsula: Further constraints from new ion-microprobe data. Polarforschung 68, 171-178.

Pogrebitsky Yu.E., 1971. Paleotectonic Analysis of the Taimyr Fold System. Nedra, Leningrad, 284 p. (in Russian) [Погребиџкий Ю.Е. Палеотектонический анализ Таймырской складчатой системы. Л.: Недра, 1971. 284 с.].

Priyatkina N., Collins W.J., Khudoley A., Zastrozhnov D., Ershova V., Chamberlain K., Shatsillo A., Proskurnin V., 2017. The Proterozoic evolution of northern Siberian craton margin: a comparison of U-Pb-Hf signatures from sedimentary units of the Taimyr orogenic belt and the Siberian platform. International Geology Review 59 (13), 1632-1656. https://doi.org/10.1080/00206814.2017.1289341.

Proskurnin V.F. Gavrish A.V., Mezhubovsky V.V., Trofimov V.R., Egorov V.N., Sobolev N.N., Naumov M.V., Vasiliev B.S., Nagaitseva N.N., Mozoleva I.N., Chernenko N.Ya., Mezhubovskaya O.A., Tarnogradsky V.D., Bagaeva A.A., Kyamyarya V.V., Shmanyak A.V., Zaika Yu.V., Gorbatsevich N.R., Petrushkov B.S., Matyushev A.P., Gusev E.A., Romashchenko O.G., 2009. State Geological Map of the Russian Federation. Scale 1:1000000 (third generation). Sheet S-48 - Lake Taimyr (Eastern Part). Explanatory Note. VSEGEI Cartographic Factory, Saint Petersburg, 253 p. (in Russian) [Проскурнин В.Ф. Гавриш А.В., Межубовский В.В., Трофимов В.Р., Егоров В.Н., Соболев Н.Н., Наумов М.В., Васильев Б.С., Нагайцева Н.Н., Мозолева И.Н., Черненко Н.Я., Межубовская О.А., Тарноградский В.Д., Багаева А.А., Кямяря В.В., Шманяк А.В., Заика Ю.В., Горбацевич Н.Р., Петрушков Б.С., Матюшев А.П., Гусев Е.А., Ромащенко О.Г. Государственная геологическая карта Российской Федерации. Масштаб 1:1000000 (третье поколение). Лист S-48 оз. Таймыр (восточная часть). Объяснительная записка. СПб.: Картфабрика ВСЕГЕИ, 2009. 253 с.].

Proskurnin V.F., Vernikovsky V.A., Metelkin D.V., Petrushkov B.S., Vernikovskaya A.E., Gavrish A.V., Bagaeva A.A., Matushkin N.Yu., Vinogradova N.P., Larionov A.N., 2014. Rhyolite-granite association in the Central Taimyr zone: Evidence of accretionary-collisional events in the Neoproterozoic. Russian Geology and Geophysics 55 (1), 18-32. https:// doi.org/10.1016/j.rgg.2013.12.002.

Sobolevskaya R.F., Kaban'kov V.Ya., 2014. Stratigraphy of the Cambrian deposits of Mountainous Taimyr. In: Proceedings of Scientific Research Institute of Arctic Geology (NIIGA) - VNII Okeangeologia. Vol. 228. VNIIOkeangeologia, Saint Petersburg, 43 p. (in Russian) [Соболевская Р.Ф., Кабаньков В.Я. Стратиграфия кембрийских отложений Горного Таймыра. Труды НИИГА - ВНИИОкеангеология. Т. 228. СПб.: ВНИИОкеангеология, 2014. 43 с.].

Stepanov G.I., Tarutin O.A., Uspenskaya I.B., Schekotov M.V., Garskov V.S., 1965. Geology and Mineral Resources in the Area between the Zhdanov, Faddey and Pregradnaya Rivers. Materials for the State Geological Map, scale 1:200000. Sheets T-48-XXXIV, XXXV, XXXVI (unpublished report. Scientific Research Institute of Arctic Geology 
A.B. Kuzmichev et al.: The pre-Vendian (640-610 Ma) granite magmatism in the Central Taimyr fold belt...

(NIIGA), Leningrad (in Russian) [Степанов Г.И., Тарутин О.А., Успенская И.Б., Щекотов М.В., Гарсков В.С. Геологическое строение и полезные ископаемые междуречья Ждановой, Фаддея и Преградной. Материалы к Государственной геологической карте масштаба 1:200000 (лист T-48-XXXIV, XXXV, XXXVI) (Неопубликованный отчет). Л.: НИИГА, 1965].

Uflyand A.K., Natapov L.M., Lopatin V.M., Chernov D.V., 1991. On the tectonic nature of Taimyr. Geotektonika (Geotectonics) (6), 76-93 (in Russian) [Уфлянд А.К., Натапов Л.М., Лопатин В.М., Чернов Д.В. О тектонической природе Таймыра // Геотектоника. 1991. № 6. С. 76-93].

Vernikovskii V.A., Kotov A.B., Ponomarchuk V.A., Sal'nikova E.B., Kovach V.P., Travin A.V., 1997. Late Riphean - Vendian event in the Northern Taimyr evolution: evidence from Sm-Nd, Rb-Sr, and K-Ar dating of the garnet amphibolites of the Stanovaya ophiolite belt. Transactions (Doklady) of the Russian Academy of Sciences / Earth Science Sections 352 (1), 11-14.

Vernikovsky V.A., 1996. Geodynamic Evolution of the Taimyr Folded Region. Publishing House of SB RAS, SRC UIGGM, Novosibirsk, 203 p. (in Russian) [Верниковский B.A. Геодинамическая эволюция Таймырской складчатой области. Новосибирск: Издательство СО РАН, НИЦ ОИГГМ, 1996. 203 с.].

Vernikovsky V.A., Vernikovskaya A.E., 2001. Central Taimyr accretionary belt (Arctic Asia): Meso-Neoproterozoic tectonic evolution and Rodinia breakup. Precambrian Research 110 (1-4), 127-141. https://doi.org/10.1016/ S0301-9268(01)00184-X.

Vernikovsky V., Vernikovskaya A., Pease V., Gee D., 2004. Neoproterozoic orogeny along the margins of Siberia. In: D.G. Gee, V. Pease (Eds.), The Neoproterozoic timanide orogeny of Eastern Baltica. Geological Society, London, Memoirs, vol. 30, p. 233-248. https://doi.org/10.1144/GSL.MEM.2004.030.01.18.

Whalen J.B., Currie K.L., Chappell B.W., 1987. A-type granites: Geochemical characteristics, discrimination and petrogenesis. Contributions to Mineralogy and Petrology 95 (4), 407-419. https://doi.org/10.1007/BF00402202.

Williams I.S., 1998. U-Th-Pb geochronology by ion microprobe. In: M.A. McKibben, W.C. Shanks, W.I. Ridley (Eds.), Applications of microanalytical techniques to understanding mineralizing processes. Reviews in Economic Geology, vol. 7, p. 1-35. https://doi.org/10.5382/Rev.07.01.

Zabiyaka A.I., Zabiyaka I.D., Vernikovsky V.A., Serdyuk S.S., Zlobin M.N., 1986. Geology and Tectonic Evolution of Northeast Taimyr. Nauka, Novosibirsk, 144 p. (in Russian) [Забияка А.И., Забияка И.Д., Верниковский В.А., Сердюк С.С., Злобин М.Н. Геологическое строение и тектоническое развитие Северо-Восточного Таймыра. Новосибирск: Наука, 1986. 144 с.].

Zonenshain L.P., Kuzmin M.I., Natapov L.M., Page B.M. (Eds.), Geology of the USSR: A Plate-Tectonic Synthesis. AGU Geodynamics Series, vol. 21, 242 p. https://doi.org/10.1029/GD021.

\section{Aleksander B. Kuzmichev}

Doctor of Geology and Mineralogy

Geological Institute of RAS

7 Pyzhevsky lane, Moscow 119017, Russia

e-mail: nsi.kuzmich@yandex.ru

(iD) https://orcid.org/0000-0002-1595-1744

Maria K. Danukalova

Candidate of Geology and Mineralogy

Geological Institute of RAS

7 Pyzhevsky lane, Moscow 119017, Russia

e-mail: danukalovamk@yandex.ru

https://orcid.org/0000-0002-2974-3065

\section{Александр Борисович Кузьмичев}

докт. геол.-мин. наук

Геологический институт РАН

119017, Москва, Пыжевский пер., 7, Россия

Мария Константиновна Данукалова

канд. геол.-мин. наук

Геологический институт РАН

119017, Москва, Пыжевский пер., 7, Россия 
Vasily F. Proskurnin

Doctor of Geology and Mineralogy

A.P. Karpinsky Russian Geological Research Institute (VSEGEI)

74 Sredny ave. V.O., Saint Petersburg 199106, Russia

e-mail: vasily_proskurnin@vsegei.ru

(iD) https://orcid.org/0000-0002-6424-0068

Aleksandra A. Bagaeva

Candidate of Geology and Mineralogy

A.P. Karpinsky Russian Geological Research Institute (VSEGEI)

74 Sredny ave. V.O., Saint Petersburg 199106, Russia

iD https://orcid.org/0000-0001-7675-2020

\section{Nikolai I. Berezyuk}

A.P. Karpinsky Russian Geological Research Institute (VSEGEI)

74 Sredny ave. V.O., Saint Petersburg 199106, Russia

https://orcid.org/0000-0002-3109-2943

\section{Petr A. Gromov}

A.P. Karpinsky Russian Geological Research Institute (VSEGEI)

74 Sredny ave. V.O., Saint Petersburg 199106, Russia

e-mail: petr_gromov@vsegei.ru

(iD) https://orcid.org/0000-0001-6957-5716

\section{Василий Федорович Проскурнин}

докт. геол.-мин. наук

Всероссийский научно-исследовательский геологический институт им. А.П. Карпинского

199106, Санкт-Петербург, Средний проспект В.О., 74, Россия

\section{Александра Александровна Багаева}

канд. геол.-мин. наук

Всероссийский научно-исследовательский геологический институт им. А.П. Карпинского

199106, Санкт-Петербург, Средний проспект В.0., 74, Россия

\section{Николай Игоревич Березюк}

Всероссийский научно-исследовательский геологический институт им. А.П. Карпинского

199106, Санкт-Петербург, Средний проспект В.0., 74, Россия

\section{Петр Андреевич Громов}

Всероссийский научно-исследовательский геологический институт им. А.П. Карпинского

199106, Санкт-Петербург, Средний проспект В.0., 74, Россия 